INTER NATIONAL MONETARY FUND
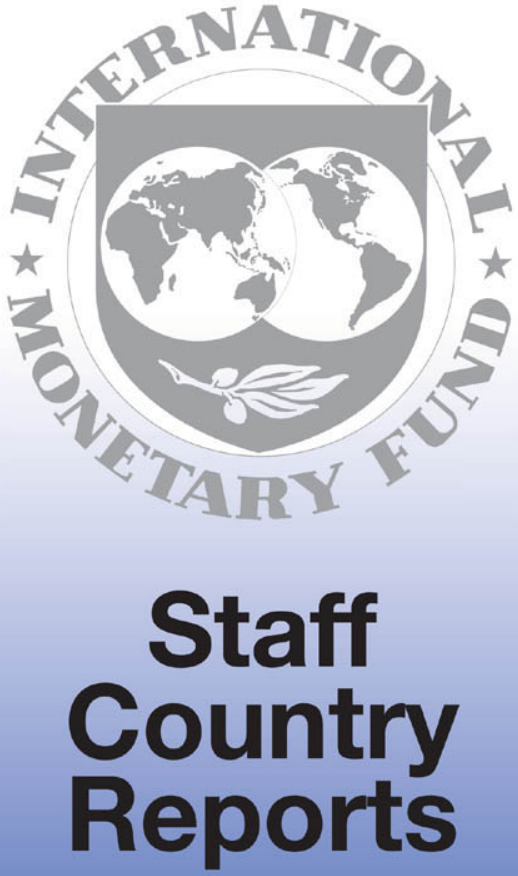


\title{
Lebanon: 2009 Article IV Consultation and Assessment of Performance Under the Program Supported by Emergency Post-Conflict Assistance-Staff Report; Public Information Notice on the Executive Board Discussion; and Statement by the Executive Director for Lebanon
}

Under Article IV of the IMF's Articles of Agreement, the IMF holds bilateral discussions with members, usually every year. In the context of a combined discussion of the 2009 Article IV consultation with Lebanon and the assessment of performance under the program supported by the emergency post-conflict assistance, the following documents have been released and are included in this package:

- $\quad$ The staff report for the combined 2009 Article IV Consultation and Assessment of Performance Under the Program Supported by Emergency Post-Conflict Assistance, prepared by a staff team of the IMF, following discussions that ended on March 5, 2009, with the officials of Lebanon on economic developments and policies. Based on information available at the time of these discussions, the staff report was completed on March 31, 2009. The views expressed in the staff report are those of the staff team and do not necessarily reflect the views of the Executive Board of the IMF.

- $\quad$ A Public Information Notice (PIN), summarizing the views of the Executive Board as expressed during its April 15, 2009, discussion of the staff report on issues related to the Article IV consultation and the IMF arrangement, respectively.

- $\quad$ A statement by the Executive Director for Lebanon.

The policy of publication of staff reports and other documents allows for the deletion of market-sensitive information.

Copies of this report are available to the public from

International Monetary Fund $\bullet$ Publication Services

$70019^{\text {th }}$ Street, N.W. $\bullet$ Washington, D.C. 20431

Telephone: (202) 623-7430 • Telefax: (202) 623-7201

E-mail: publications@imf.org•Internet: http://www.imf.org

\author{
International Monetary Fund \\ Washington, D.C.
}


This page intentionally left blank

(CInternational Monetary Fund. Not for Redistribution 


\title{
INTERNATIONAL MONETARY FUND
}

\section{LEBANON}

\section{Staff Report for the 2009 Article IV Consultation and Assessment of Performance Under the Program Supported by Emergency Post-Conflict Assistance}

\author{
Prepared by Middle East and Central Asia Department \\ (In consultation with other departments) \\ Approved by Ratna Sahay and Ranil Salgado
}

March 31, 2009

- $\quad$ Team: Mr. Fanizza (head), Mr. Gardner (Senior Resident Representative), Messrs. Finger and Sdralevich (all MCD), Lopez Murphy (FAD) and Weisfeld (SPR).

- Mission dates: February 19-March 5, 2009.

- Counterparts: central bank governor; ministers of finance, economy and trade, labor, telecommunications, tourism, and energy; members of parliament and political parties, the Banking Control Commission (BCC), senior government officials, and representatives of the banking sector, the business community, and donor countries.

- Communication: The mission held a closing press conference together with the minister of finance (http://www.imf.org/external/np/sec/pr/2009/pr0963.htm).

- Use of Fund Resources: Two drawings under Emergency Post-Conflict Assistance (EPCA) in April 2007 (25 percent of quota or SDR 50.75 million) and in November 2008 (12.5 percent of quota or SDR 25.375 million).

- 2007 Article IV consultation: concluded by the Executive Board on October 3, 2007 (http://www.imf.org/external/pubs/cat/longres.cfm?sk=21510.0).

- $\quad$ Article VIII: Lebanon has accepted the obligations of Article VIII, Sections 2, 3, and 4 in 1993 and maintains an exchange system free of restrictions on the making of payments and transfers for current international transactions. The exchange rate regime is a conventional pegged arrangement, with the Lebanese pound kept around a mid-point parity of LL 1,507.5 per U.S. dollar since October 1999.

- Lebanon participates in the General Data Dissemination Standards. The fiscal ROSC was published May 16, 2005, and the last FSAP update was concluded in 2001.

- $\quad$ This report reflects information through March 20, 2009. 


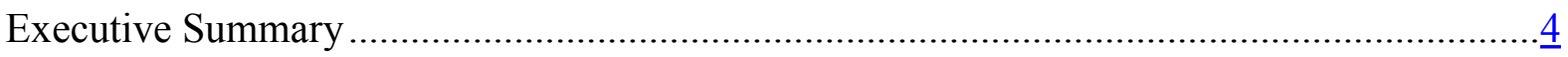

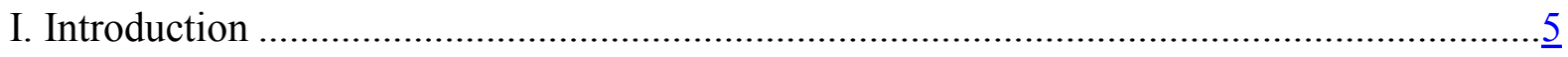

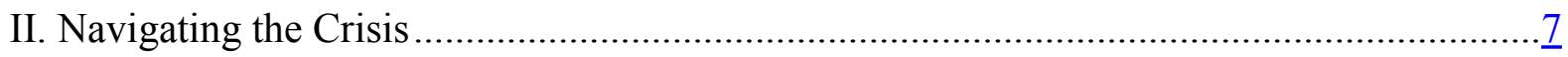

III. Authorities' Policies for 2009 …...............................................................................

A. Maintaining a Strong Reserve Buffer in Times of Uncertainty …….....................13

B. Containing the Government's Financing Needs and Reducing Debt ….................14

C. Strengthening the Banking Sector ......................................................................

IV. Medium-Term Plans to Tackle Vulnerabilities ............................................................... 18

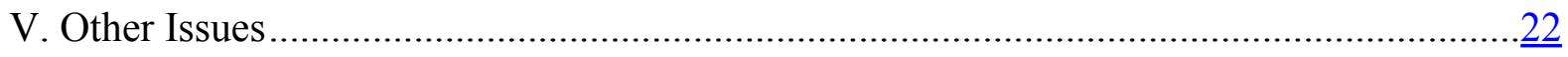

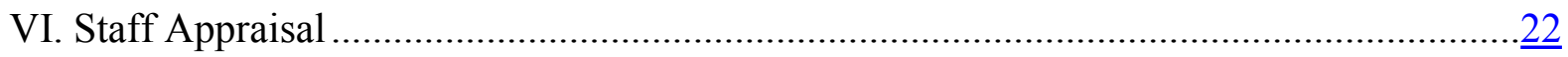

Boxes

1. Performance Under EPCA and Implementation of Past Fund Advice ...............................

2. The Lebanese Banking Sector in the Face of the Global Crisis .......................................

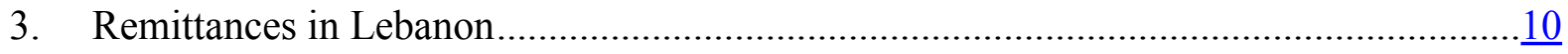

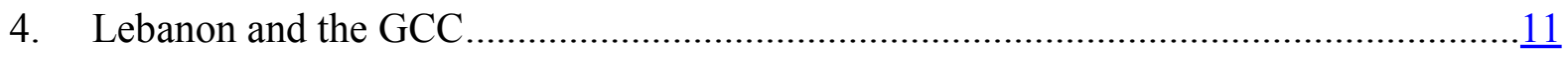

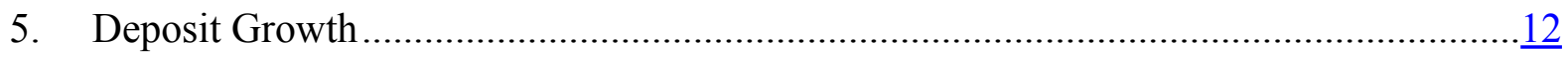

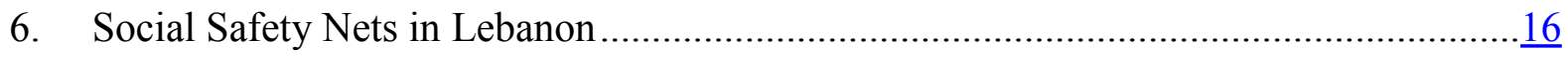

7. Shock Scenarios for Debt Sustainability Analysis.....................................................

\section{Text Figures}

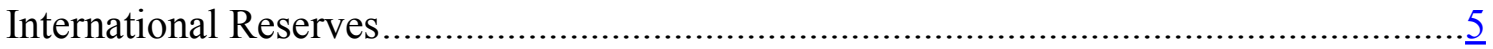

Eurobond and Credit Default Swap Spreads ……….................................................. $\frac{5}{7}$

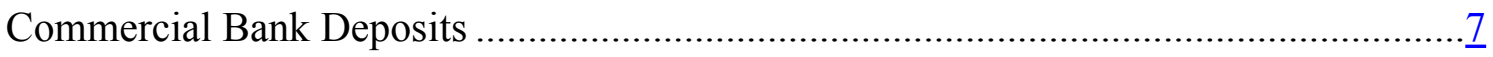

Deposit Dollarization and Interest Rate Spread .......................................................

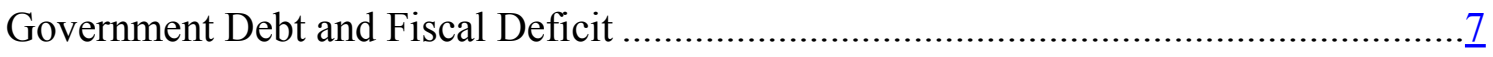

Contribution to Headline CPI Inflation...................................................................

GDP Growth and Coincident Activity Indicator, 2005-08 …...................................... $\underline{8}$

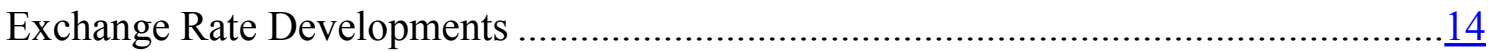

Government FX Debt Service..............................................................................

\section{Text Tables}

Real Exchange Rate Overvaluation Estimates Using CGER Approaches ……………...13

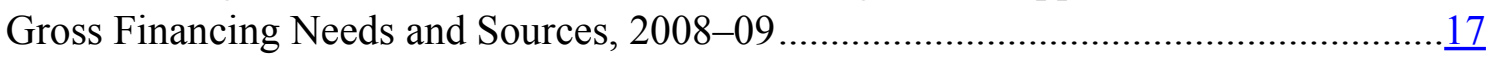

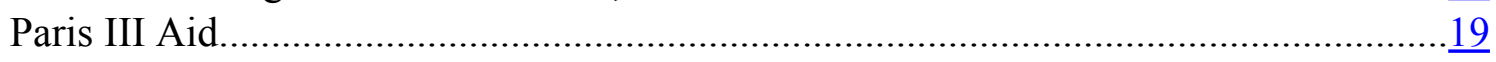

Projected Yield from the Authorities' Fiscal Measures, 2010-14 .................................19 
Figure

1. Public Debt Sustainability, 2004-14

Tables

1. Selected Economic Indicators, 2006-14. .$\underline{26}$

2. Central Government Overall Deficit and Financing, 2006-14 (In billions of Lebanese pounds).

3. Central Government Overall Deficit and Financing, 2006-14 (In percent of GDP) .$\underline{28}$

4. Government Debt, 2006-14 ................................................................................29

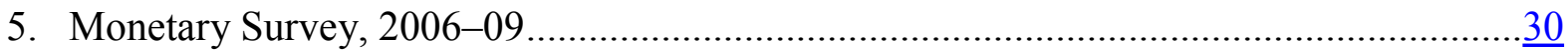

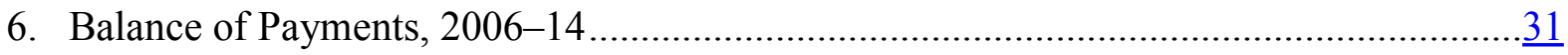

7. Banking Sector Financial Soundness Indicators, 2006-08 ….....................................32

8. Public Sector Debt Sustainability Framework, 2006-14 ............................................33

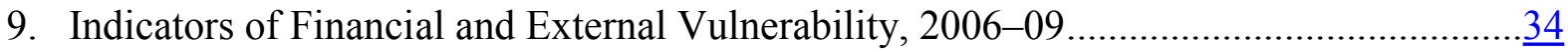

10. External Financing Requirements and Sources, 2006-10 ........................................

11. Indicators of Capacity to Repay the Fund, 2006-14.................................................. $\underline{36}$

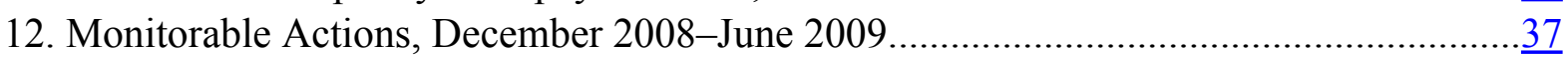

13. Quantitative Indicative Targets Under the Program Supported by Emergency Post-Conflict Assistance, December 2008-June 2009 


\section{EXECUTIVE SUMMARY}

\section{Impact of the crisis}

Despite its large vulnerabilities, Lebanon has so far weathered the global financial crisis and succeeded in maintaining financial stability, raising international reserves, and reducing public debt in 2008. The economy achieved record growth, and Eurobond spreads are now lower than the emerging market average. Fund engagement in Lebanon through the EPCA (which was broadly on track at end-December) has contributed to this performance. Lower global liquidity and the world economic downturn, particularly in the Gulf, will likely affect Lebanon in 2009, with lower growth and deposit inflows.

\section{Policy discussions}

Lebanon's economy and financial system face three key risks: a larger-than-expected impact of the global recession and slowdown in the Gulf; more difficult-than-anticipated government financing; and political and security shocks, particularly in coincidence with the June elections. To address these risks, the authorities intend to:

- $\quad$ Further accumulate reserves to preserve confidence through a sufficiently high interest rate differential between domestic currency and foreign currency rates;

- Maintain the debt-to-GDP ratio constant to protect fiscal achievements and allowing the 2009 financing needs to be met from the market, while addressing the potential social needs arising from the effects of the global recession;

- Step up their vigilance over the banking sector, as banks could be hit by a stronger-than-expected fall in deposit growth or a worsening in loan quality.

The Paris III agenda will remain the anchor for medium-term plans focusing on continued fiscal consolidation mainly through revenue measures, such as an increase in VAT rate, and the reduction in the large losses at Electricite du Liban (EdL). In addition, the telecom privatization would boost private sector activity and further reduce the debt.

\section{Staff appraisal}

- $\quad$ Staff agrees with the authorities' view of the risks in 2009, particularly in light of their possible combined effect, which warrant the preparation of contingency plans;

- $\quad$ Monetary and exchange rate policy is broadly appropriate, but, given the downside risks, staff recommended a tighter fiscal stance in 2009 to keep unchanged financing requirements and ensure continued debt reduction;

- $\quad$ Restarting the medium-term Paris III agenda should be priority after the elections. 


\section{INTRODUCTION}

\section{Despite its large vulnerabilities, Lebanon has so far weathered the global}

financial crisis. Lebanon's public debt-to-GDP ratio remains among the highest in the world. Its banking system, with assets of more than three times nominal GDP, is highly exposed to the sovereign, and dependent on deposit inflows from nonresidents. Moreover, the country lies at the crossroads of regional and international political tensions. Despite these challenges, Lebanon has managed to maintain financial stability since the global crisis erupted in September 2008. There have been no pressures on the peg so far, and the Banque du Liban (BdL) has continued to accumulate international reserves at a swift pace. Deposit inflows took a short breather after the Lehman failure, but have resumed at a rapid pace since then, and deposit dollarization has declined steadily. Eurobond and Credit Default Swap (CDS) spreads are now below the emerging market average, and the banking system has withstood the global financial crisis.
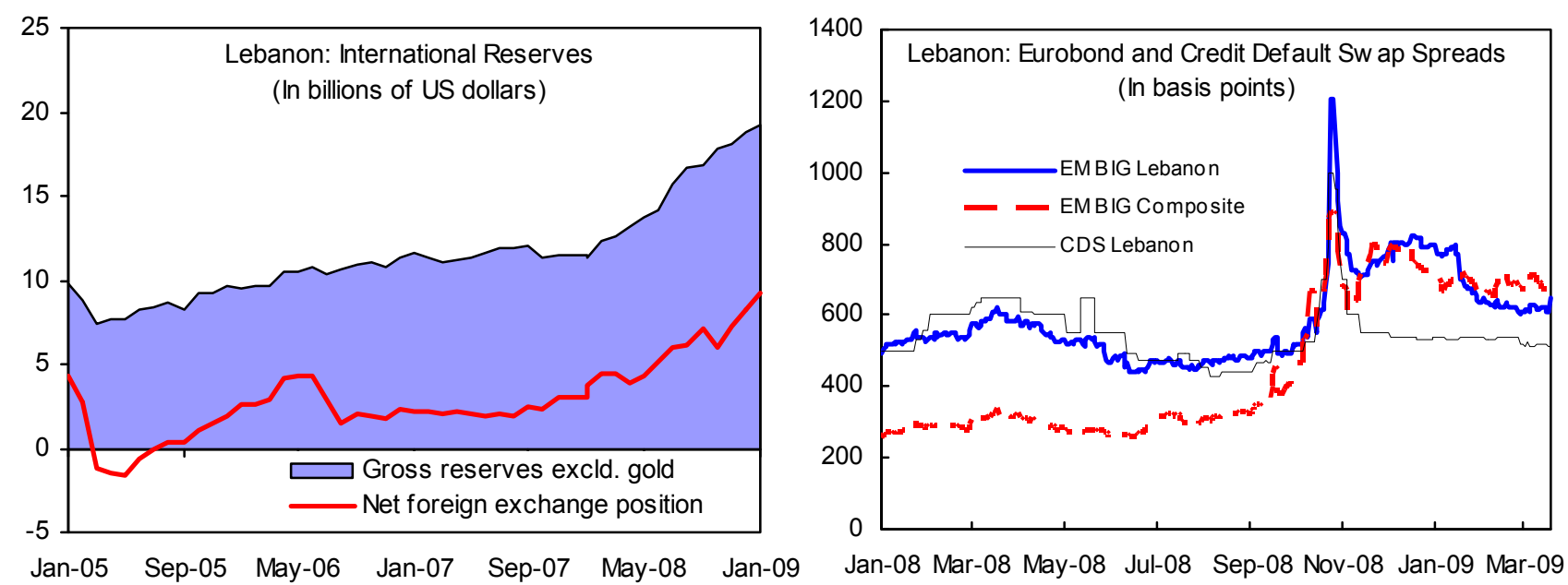

2. The improved political and security situation has been crucial to this outcome.

The Doha agreement in May 2008 put an end to the armed fighting between supporters of the majority and minority coalitions, and opened the way to the formation of a unity government to take the country to the June 2009 general elections.

\section{Fund engagement in Lebanon through the EPCA policy has contributed to} the economy's resilience. The authorities' macroeconomic policies have been supported by the international community-most notably at the Paris III donor conference in January 2007 - and by the Fund, through a quarterly monitoring framework and two drawings under the Emergency Post-Conflict Assistance policy, in April 2007 and November 2008. 


\section{Box 1. Performance Under EPCA and Implementation of Past Fund Advice}

The end-December 2008 quantitative indicative targets have been met, but there are some slippages in structural policies. The primary balance excluding grants and net government borrowing from the BdL have comfortably met the respective targets, and gross international reserves of the BdL have exceeded the target by $\$ 1.8$ billion (around 10 percent of reserves). Lower oil prices have reduced the pressure to adjust electricity tariffs (though electricity subsidies remain significant), resulting in the non-observance of the corresponding end-December monitorable action. In January 2009, the BdL established an investment committee and prepared formal guidelines for foreign reserve management (end-December monitorable action).

The authorities also reported progress toward achieving the end-March monitorable actions. In part due to the worse international financial conditions, telecom privatization has been postponed, and the associated monitorable action to launch the request for applications will not be met. The draft Global Income Tax bill will be submitted to the Council of Ministers by end-March and soon thereafter to Parliament, likely implying a minor delay in the corresponding monitorable action. The BdL has already adopted the policies for the selection, appointment, and rotation of external auditors (end-June monitorable action).

Economic policy since the Paris III conference has been broadly in line with the Fund's policy advice. The Paris III medium-term economic and reform program was developed in close consultation with staff. While the planned fiscal consolidation and structural reforms have repeatedly been postponed due to the difficult security situation and the worsening of the political tensions between the government and the opposition, the Paris III program remains the anchor for medium-term policy objectives. Implementation of the program supported by the first drawing under EPCA was successful despite slippages in structural policies. The Fund has supported the authorities' view that the peg remains instrumental in maintaining financial stability.

\section{Policy discussions focused on the authorities' objectives:}

- In the near term, safeguarding the recent progress, in particular with regard to international reserve accumulation and fiscal consolidation, and preparing the economy to withstand the impact of a deepening global economic and financial crisis;

- In the medium term, relaunching the Paris III agenda, and in particular sustained debt reduction and structural reform. 


\section{Navigating The CRisis}

\section{The authorities' policies in $\mathbf{2 0 0 8}$ put Lebanon in a position to weather the first round impact of the crisis:}

- Monetary and exchange rate policy aimed at building up international reserves.

To this end, the BdL allowed a growing deposit interest rate differential in favor of the local currency in order to maintain confidence in the Lebanese financial system, attract deposit inflows, and promote a de-dollarization of deposits.
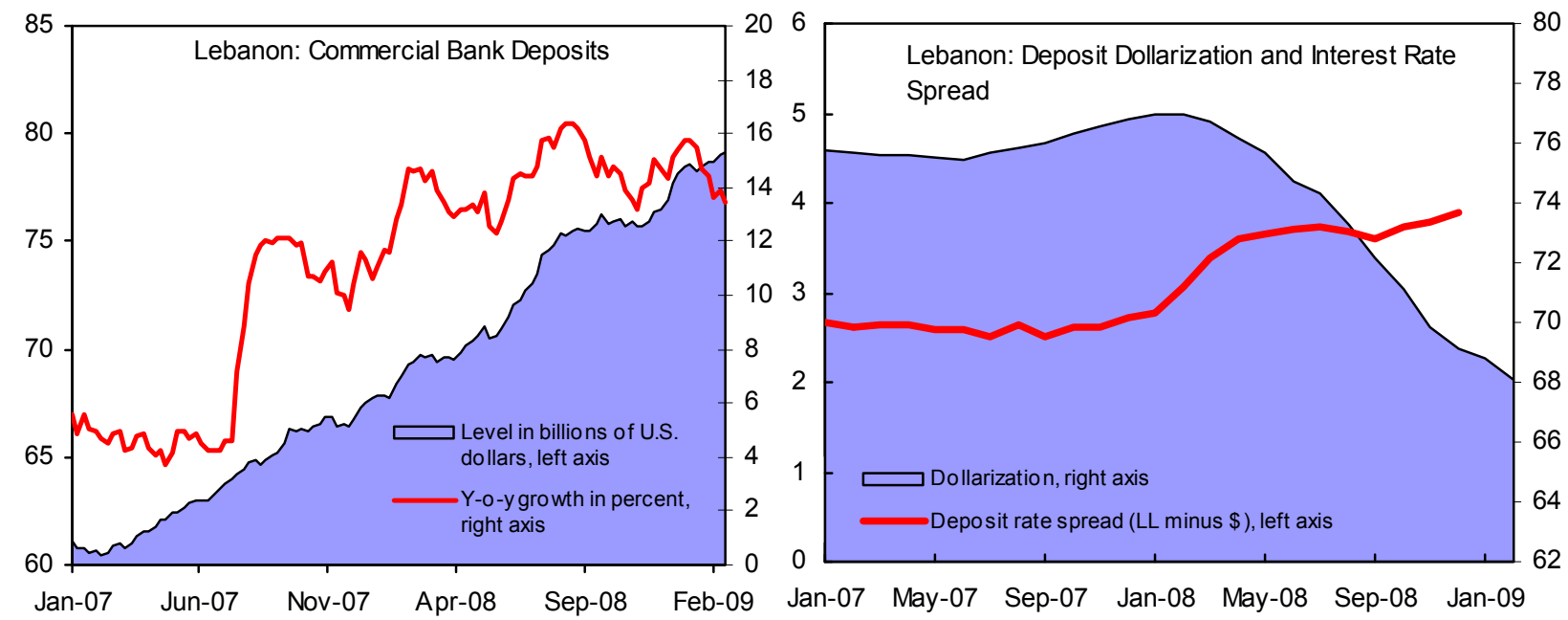

Fiscal policy capitalized on the 2008 growth dividend to achieve further reduction in public debt. Revenues increased, following the unprogrammed reintroduction of the gasoline excises, made politically more acceptable by lower oil prices. ${ }^{1}$ The primary fiscal balance (excluding grants) reached 0.5 percent of GDP in 2008, helping the public debt decrease from 168 to 162 percent of GDP in the course of the year.

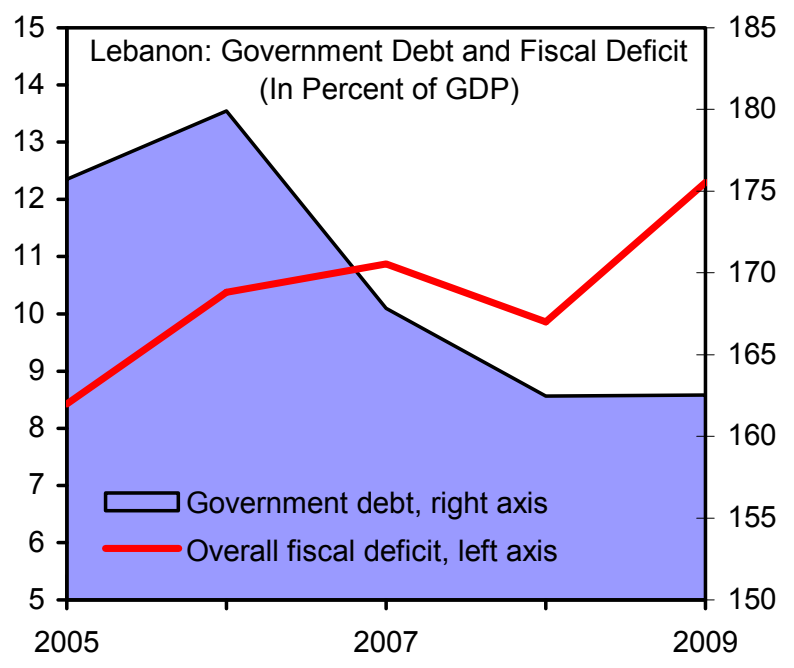

\footnotetext{
${ }^{1}$ In January 2009, the authorities fixed the excise level at fixed at LL470 and uncapped the price of gasoline.
} 
6. Given the improved political and macroeconomic situation, Lebanon achieved record growth in 2008. With a pick-up in activity in the second half of the year driven by construction and tourism, real GDP achieved a growth of more than 8 percent for the year. In line with international prices, inflation declined to 4 percent in January 2009. Despite a strong export performance ( 26 percent growth in 2008), high oil prices and strong domestic demand pushed the current account deficit to over 11 percent in 2008.

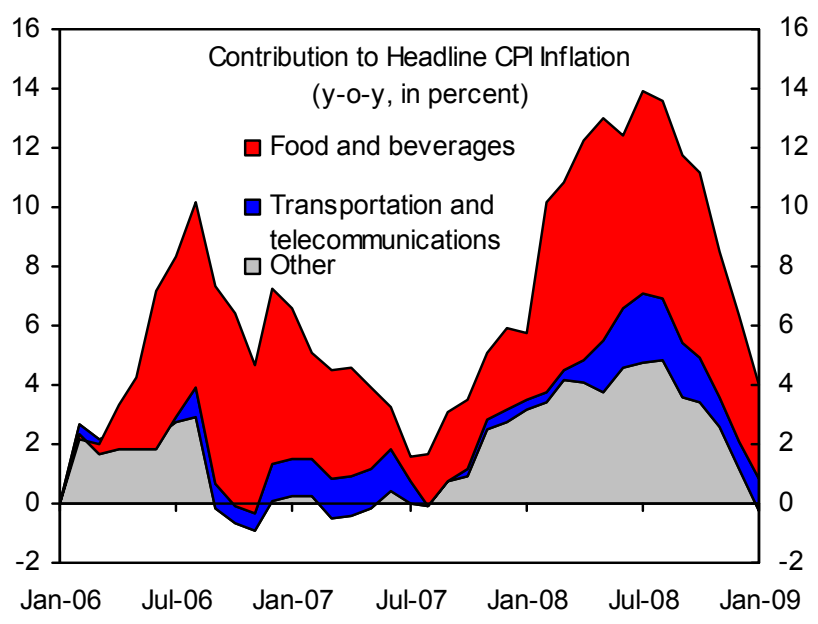

Lebanon: GDP Growth and Coincident Activity Indicator, 2005-08

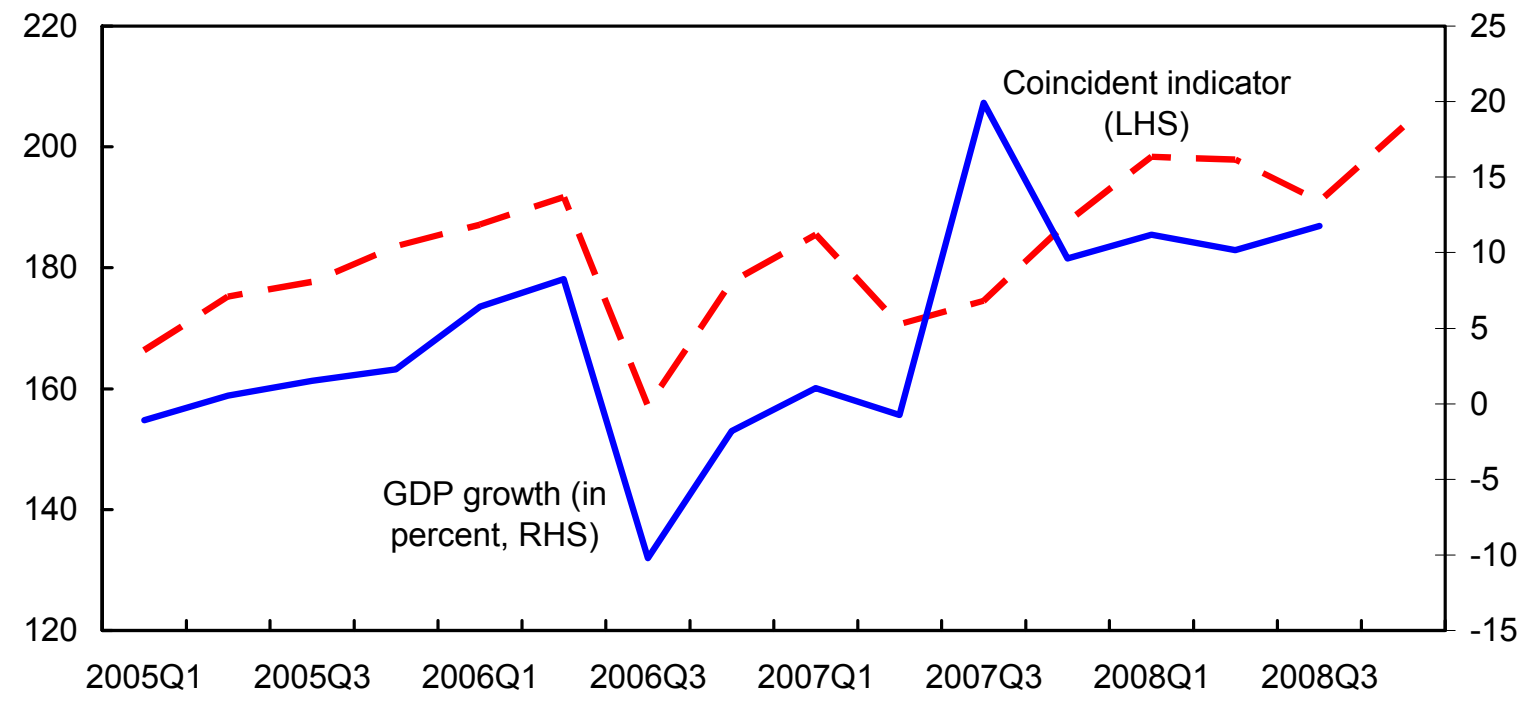

7. However, the worsening international macroeconomic outlook will affect

Lebanon in 2009. The authorities expect lower global liquidity and the world economic downturn, particularly in the Gulf, to affect remittances, tourism, foreign direct and portfolio investment, as well as deposit inflows. Thus, growth is likely to slow to 3 percent this year from over 8 percent in 2008, and deposit growth is expected to decline to 10 percent from 15 percent in 2008. Inflation will remain low, in line with international price trends. Lower oil prices will reduce the current account deficit, even though the capital account will likely weaken due to lower investment flows. 


\section{Box 2. The Lebanese Banking Sector in the Face of the Global Crisis}

\section{Banks have so far been little affected by the global financial crisis.}

- While commercial bank assets amount to 324 percent to GDP, one of the highest ratios among emerging markets, banks source around 90 percent of their non-equity funding from deposits, which has served them well as global wholesale funding dried up. The relationship-based banking system and the large Lebanese diaspora support a solid deposit base that has proven resilient in the past even when faced with large domestic shocks. Banks also maintain large liquidity buffers, with a 50 percent ratio of liquid assets to short-term liabilities (including deposits).

- Banks have also been largely insulated from financial losses on their assets. High exposure to the sovereign and new growth

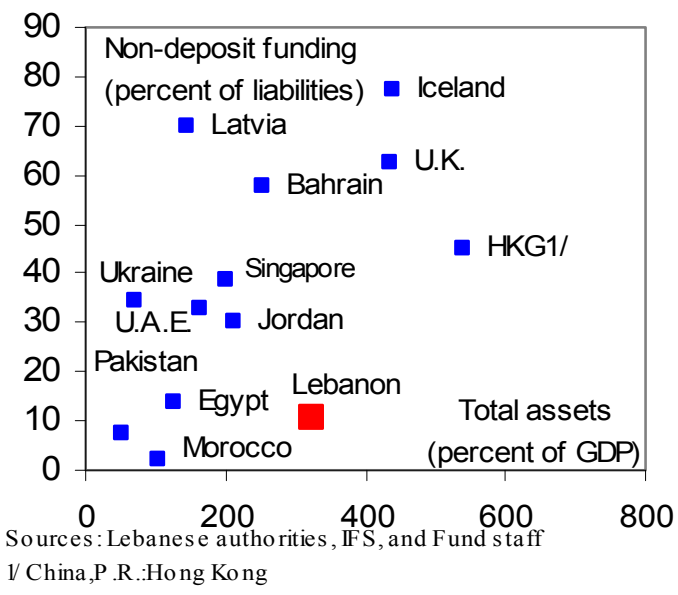
opportunities in the region have ensured bank profitability and reduced the need to search for yield in the high-risk market segments at the heart of the global crisis. Moreover, prudent bank regulation strongly discouraged exposure to structured products and limited the banks' exposure to real estate speculation. While Lebanese banks maintain

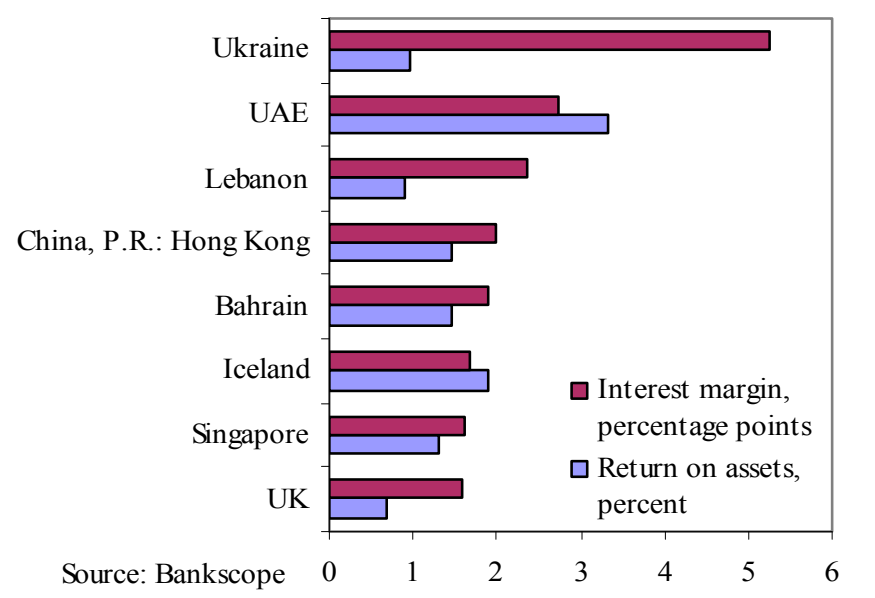
large liquid foreign assets, they did not suffer significant losses (equivalent to less than 1 percent of core capital) following the failure of Lehman and the troubles of regional banks in Kuwait and the UAE.

Banks suffer, however, from long-standing structural vulnerabilities. Commercial bank assets are concentrated on the sovereign, which accounts for 55 percent of assets. Moreover, banks carry a substantial maturity mismatch from funding their lending operations largely from short-term deposits, and a significant indirect currency exposure from foreign exchange lending to unhedged clients. Looking forward, the fall in the stock market (which at end-February had lost 26 percent year-on-year), the end of the housing boom, and the projected economic slowdown more generally could lead to an increase in non-performing loans (from 3.1 percent at end-2008), including from regional operations. However, stress tests carried out by the Banking Control Commission (BCC) have shown that banks could easily absorb a hypothetical increase in non-performing loans by 50 percent, to levels experienced after the 2006 war with Israel. 


\section{Box 3. Remittances in Lebanon}

Remittances to Lebanon are among the highest in the world. Reflecting both a rising global trend in remittances and the size of the Lebanese diaspora, gross remittances inflows have grown to an estimated 20 percent of GDP in 2008, placing the country among the largest recipients of remittances as a share of GDP in the world. With remittances outflows estimated at 8 percent of GDP, net remittances inflows amounted to 12 percent of GDP.

Top Ten Recipients of Gross Remittances, 2007

(In percent of GDP)

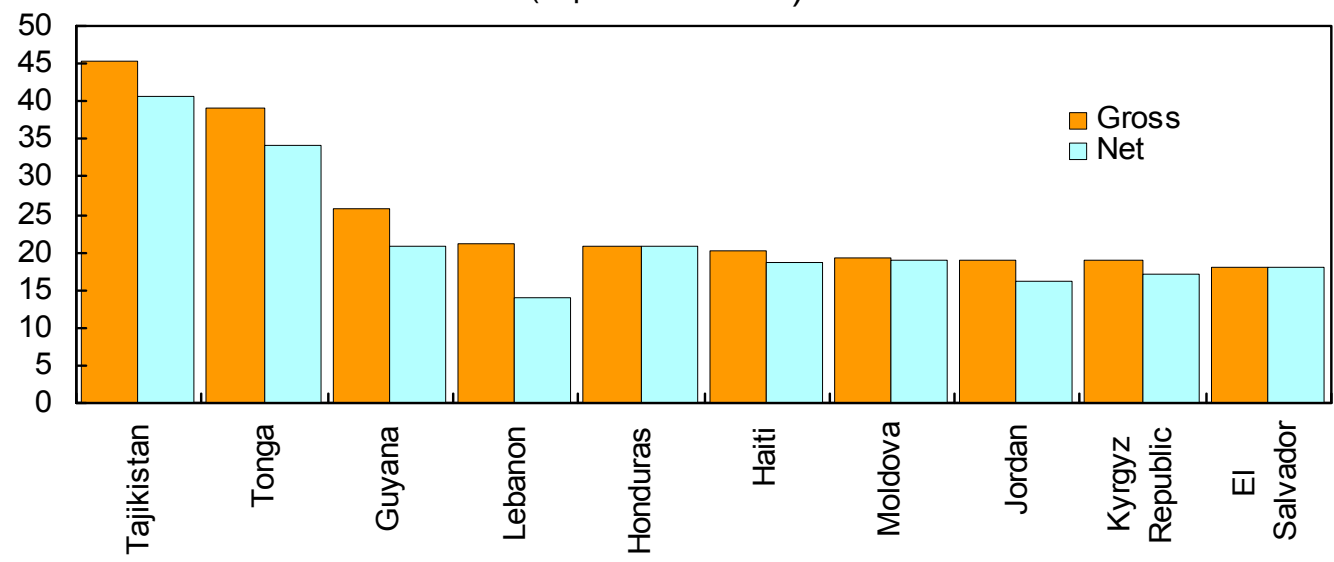

The continuing global economic downturn is likely to lead to a marked decline in remittances. Some 54 percent of remittances to Lebanon originate in the Gulf Cooperation Council (GCC) and another 16 percent in Australia, the US, and Canada. The projected decline in GDP growth in these countries in 2009 is estimated to bring about a fall in gross and net remittances inflows of up to 12 percent ( 2.4 percent of GDP) and 25 percent ( 3 percent of GDP) respectively in 2009. 


\section{Box 4. Lebanon and the GCC}

There are strong economic links between Lebanon and the GCC:

- Remittances from Lebanese living in the GCC amount to around half of total gross remittances to Lebanon. Anecdotal evidence and data on past migration flows suggest that up to 400,000 Lebanese are living in the Gulf, in large part well-educated professionals.

- The GCC countries are Lebanese exports' largest market, with a share of 24 percent in 2007.

- Tourists from the GCC are a significant fraction of total tourists to Lebanon. In 2008, they bought 48 percent of total hotel nights (excluding Lebanese nationals). GCC nationals also spend proportionately more than tourists from other countries.

- Direct investment flows from the GCC have accounted for around 60 percent of total FDI to Lebanon over the period 2002-07, more than half of which has been in real estate. Lebanon

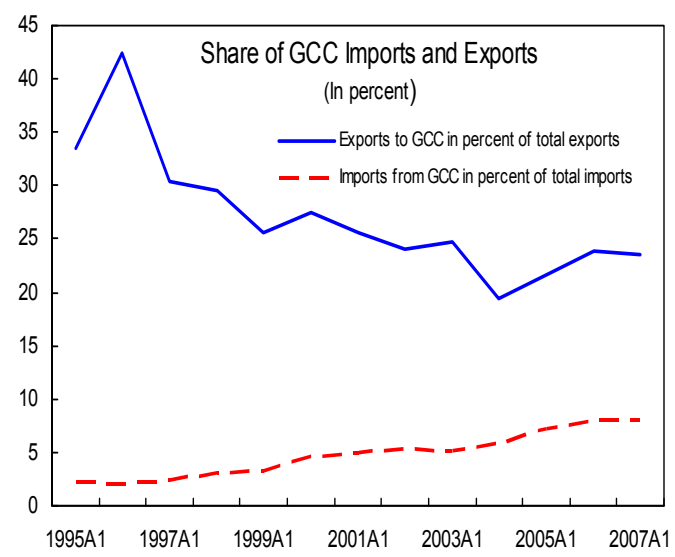
receives around one-third of all GCC investments to MENA countries. In addition, Gulf investors are thought to hold a large number of the high-value deposits at Lebanese banks.

\section{Authorities' Policies fOR 2009²}

\section{The authorities see three key risks for the Lebanese economy and financial} system, which present considerable challenges to Lebanon, particularly if they materialize at the same time:

- $\quad$ First, the global recession and slowdown in the Gulf - even if cushioned by fiscal expansion-will affect capital flows and economic activity in Lebanon. While a soft landing in Lebanon remains the most likely outcome, there is a significant downside risk to domestic activity.

- Second, government financing may become more difficult than anticipated if the fiscal stance is loosened, interest rates on government debt rise, or deposit inflows slow down.

- Third, Lebanon remains exposed to political and security shocks, particularly in the run up to the elections.

The authorities aim at minimizing the possible impact of these risks by further increasing the international reserve buffer, reducing fiscal vulnerabilities, containing financing needs, and strengthening the banking sector this year.

\footnotetext{
${ }^{2}$ Staff's views are given in Section VI.
} 


\section{Box 5. Deposit Growth}

Deposit growth remains the highest vulnerability to maintaining financial stability in Lebanon. The country's large fiscal deficits have been financed to a substantial degree by domestic banks, which source their lending capacity largely from deposit growth. A severe slowdown in deposit growth could hence impede government market financing.

Deposit growth has recently picked up markedly. Since the end of the civil war in 1990, annual deposit growth never fell below 4 percent even in the face of marked domestic shocks such as the near-debt crisis in 2002, the political turmoil after the assassination of former Prime Minister Rafik Hariri in 2005, and the 2006 war with Israel and ensuing domestic political deadlock (shaded areas in the figure below). During these crises, there were short-lived outflows that were quickly recovered. Since mid-2008, deposit growth has picked up considerably and, after a brief slowdown in the aftermath of the Lehman failure, reached 15.6 percent in December 2008.

A large share of deposit inflows comes from abroad, including the Gulf region. As a regional financial center, the Lebanese banking system sources a substantial share of its deposits from abroad. While reliable statistics are not available, anecdotal evidence points to the growing importance of the GCC, a popular destination for emigrants and migrant workers during the recent oil boom (see Box 4). Industrial countries, such as the United States, Canada, and Australia, also host a substantial share of the Lebanese diaspora and are an important source of Lebanese non-resident deposits (see Box 3).

Nonetheless, domestic factors appear to have a stronger bearing on deposit growth than trends in the Gulf. Since the mid 1990s, deposit growth has moved broadly in line with the interest differential between local currency and U.S. dollar-denominated deposits (left panel), except during episodes of domestic shocks. However, deposit growth appears also to be increasingly correlated to the economic cycle in the GCC (right panel).
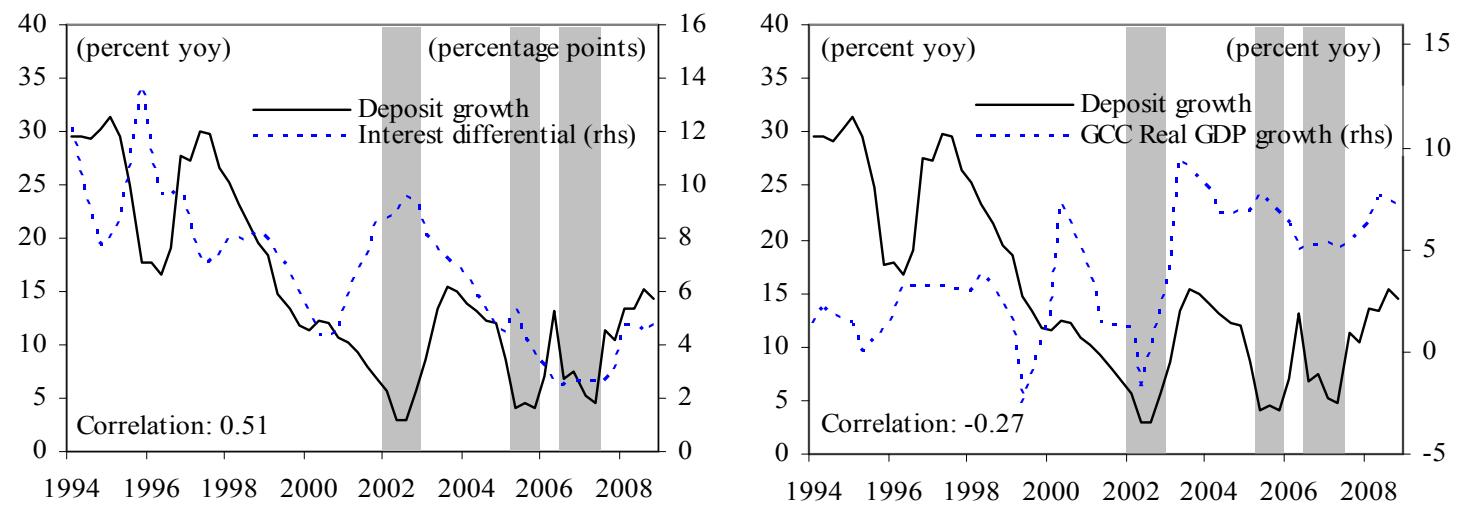


\section{A. Maintaining a Strong Reserve Buffer in Times of Uncertainty}

9. The BdL aims at further accumulating reserves to preserve confidence. To this end, the BdL intends to support deposit growth by keeping the interest rate differential between domestic currency and foreign currency rates at the current level. ${ }^{3}$ The authorities acknowledge that the policy of reserve accumulation is ultimately costly for the government, the private sector, and the BdL balance sheet. Following the elections, they would consider a further reduction in domestic currency interest rates only if deposit growth holds up at a comfortable pace.

\section{The BdL continues to be of the view that maintaining the peg will serve as the} lynchpin for Lebanon's financial stability. This is essential given the currency mismatches deriving from both widespread deposit dollarization and the government's high debt and debt service obligations in foreign currency. In the authorities' view, the lack of pressures on the peg throughout 2008 and the beginning of 2009 constitutes further evidence of the appropriateness of the exchange rate regime. Looking ahead, the authorities do not believe that the projected slowdown in exports, tourism, remittances, and capital flows will endanger the targeted build-up of international reserves within the context of the peg in 2009 , given a much reduced oil import bill and still large nonresident deposit inflows. They agree with the staff's

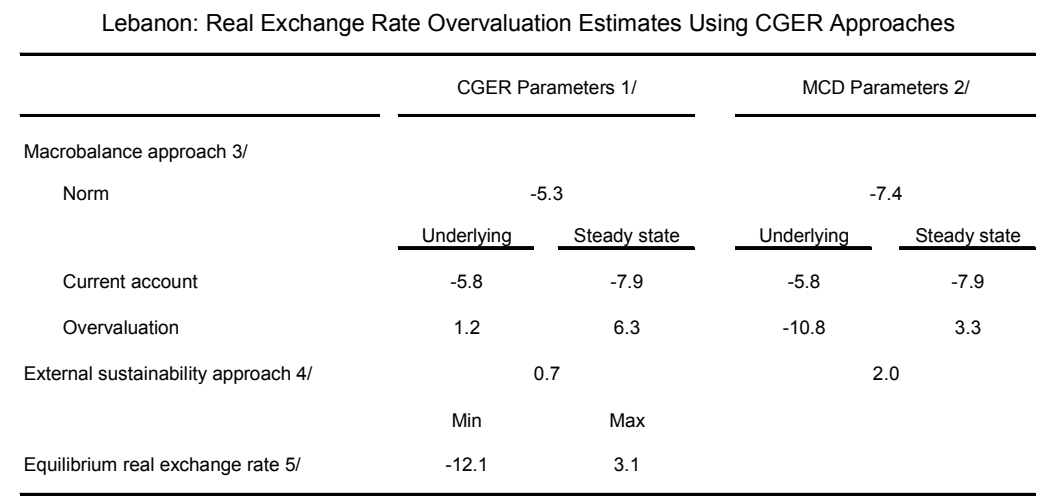

1/ Using CGER parameters and a current account elasticity of 0.4 (see IMF Country Report No. 07/382 for a description of the application of the exercise to Lebanon).

2/ Using parameters calculated for MCD oil-importing countries and a Lebanon-specific current account elasticity of 0.15. 3/ For each parametrization, compares the norms with a) underlying 2008 current account stripped of temporary factors and b) steady state (2014) current account.

4/ Derived from the net external asset position-stabilizing current account.

5/ Range of estimates obtained using different model specifications. assessment that the real effective exchange rate is not out of line with fundamentals, although the recent strength of the U.S. dollar has led to the appreciation of the Lebanese pound in real effective terms (9 percent since last August).

\footnotetext{
${ }^{3}$ The BdL's key liquidity instrument is the 5-year LL Certificate of Deposit.
} 


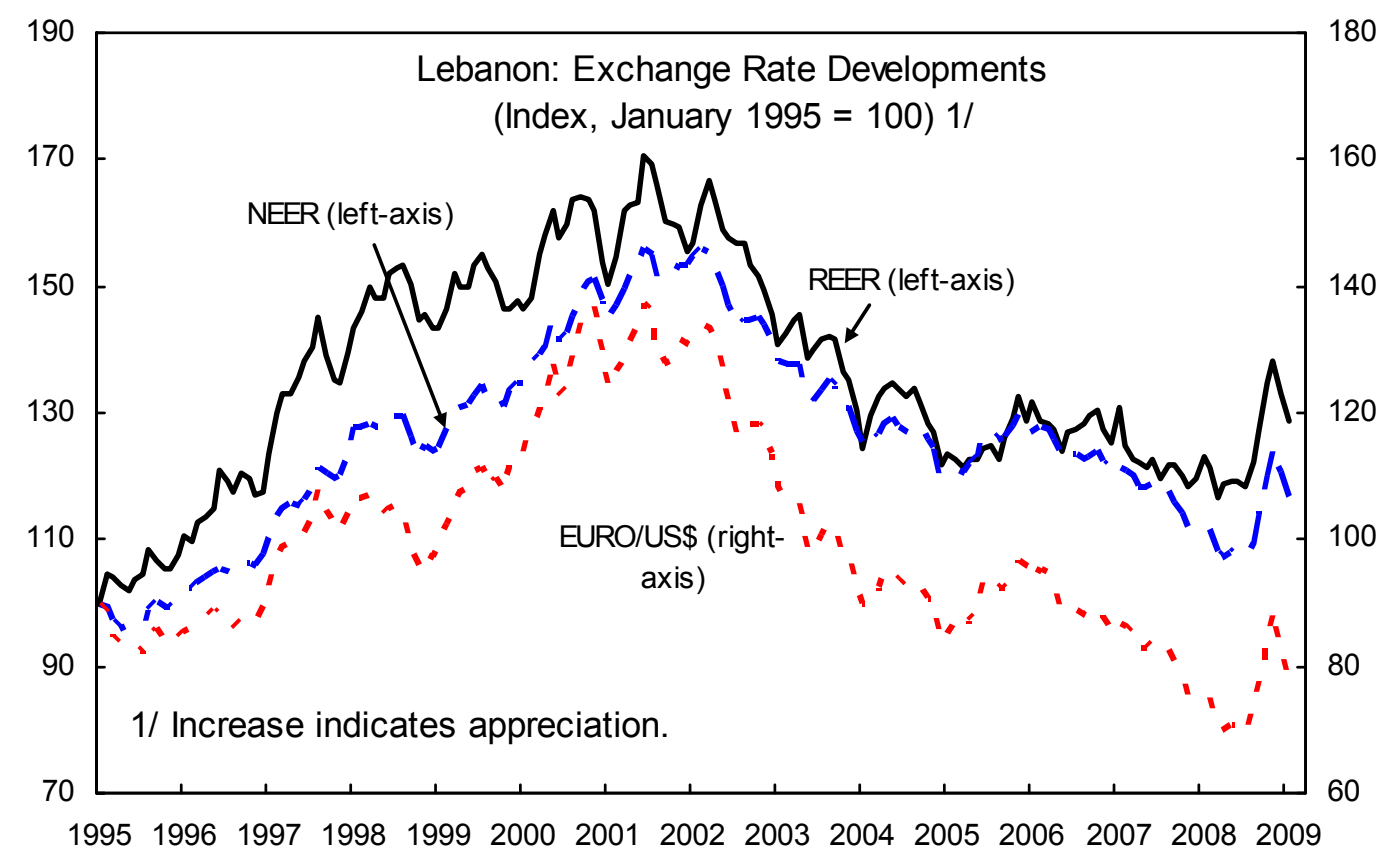

B. Containing the Government's Financing Needs and Reducing Debt

11. The authorities believe that, with the slowing down of economic activity, the process of fiscal consolidation cannot continue this year as planned. In principle, the authorities agree that domestic and external risks warrant an aggressive stance toward reducing the public debt. However, they believe that, right now, fiscal consolidation imperatives should be weighed against the potential social needs arising from the effects of the global recession and the political pressures generated by the forthcoming elections.

\section{The authorities see the $\mathbf{2 0 0 9}$ draft budget as a reasonable compromise between} these objectives. The budget envisages the primary balance (before grants) to fall to zero from 0.5 percent of GDP in 2008. The overall fiscal deficit would increase to 12.3 percent of GDP, 2.3 percentage points higher than 2008. The gross debt-to-GDP ratio would remain at 162 percent. Fiscal space has opened up this year with the reintroduction of gasoline excises and the reduced need for budgetary transfers to Electricité du Liban (EdL) arising from lower fuel costs. With delayed privatization of the mobile phone companies, the expected loss in non-tax revenue in the second half of the year will not take place. In addition, the budget includes the revenue measures envisaged under EPCA: increase in interest income tax, ${ }^{4}$ removal of VAT refunds from exempted activities, imposition of rental charges on seashore valuations, and capital gains tax on an exceptional revaluation of assets, (these measures would yield 0.6 percent of GDP). These additional resources would finance increased

\footnotetext{
${ }^{4}$ The draft budget law does not immediately introduce the interest tax rate, but grants the Cabinet the power to do so.
} 
spending in wages and salaries (+2.1 percent of GDP over 2008), a part of which related to enhancing security, and higher capital expenditures (+1.2 percent of GDP). ${ }^{5}$

13. The government is preparing an anti-crisis action package. The authorities bank on the planned wage increases and one-off payments to public sector employees to boost real incomes and prop up consumption at a time when external demand might be flagging. But, to further counter the effect of the crisis, the authorities also prepared a draft anti-crisis plan that includes an acceleration and reprioritization of infrastructure spending by the Council for Development and Reconstruction, an expansion of interest subsidies for LL-denominated bank lending to the corporate sector, various measures to improve the business climate, and incentive programs to support job creation. The plan has not yet been fully costed, but the authorities believe that it is unlikely to have a significant impact on the overall fiscal stance.

14. Budget implementation will be prudent. The implementation of the draft budget would still allow the authorities to meet the EPCA fiscal targets for March and June 2009. In case of revenue shortfall or expenditure overruns, the authorities are ready to consider additional measures to maintain the debt-to-GDP ratio constant. Should the budget fail to be approved, a significant portion of spending would be based on the 2005 budget (the last to be passed by parliament) and thus more easily contained, possibly bringing savings of up to 0.6 percent of GDP compared to the draft budget.

\footnotetext{
${ }^{5}$ The wage bill is projected to increase by 2.1 percentage points of GDP in 2009. Of this increase, 0.9 percentage points derive from the full annual impact of the wage increase approved in September 2008. The remaining 1.2 percentage points result from: a) one-off retroactive payments dating back to 1996-98 (0.65 points), b) an increase in the public sector grade scale ( 0.2 points), c) hiring of additional teachers, security personnel and contractual public workers not subject to the public sector hiring freeze ( 0.3 points), and d) a special allowance to the army ( 0.05 points).
} 


\section{Box 6. Social Safety Nets in Lebanon}

Poverty in Lebanon is high. According to the UNDP, 28 percent and 8 percent of the population in 2004-05 could be considered respectively poor and very poor. Poverty is concentrated outside Beirut, in the North and in the South of the country. The Gini coefficient, at 0.37 , was close to the MENA average; the bottom 20 percent of the population accounted for 7 percent of consumption, while the top 20 percent accounted for 43 percent of consumption.

Social spending in Lebanon is high, but its share specifically allocated to poor households (i.e., safety nets) is small. While spending in education, health, pensions and social assistance accounted approximately for 30 percent of primary expenditures in 2007 , social assistance was less than 20 percent of this amount. Significant budgetary resources are used for electricity subsidies (transfers to EDL), which absorbed 23 percent of primary spending in 2008 but mainly benefit the top income bracket customers, who consume more electricity per capita.

The effectiveness of safety nets is undermined by the lack of coordination between the various providers. Most of the benefits financed through the Ministry of Social Affairs (MoSA) are provided by a range of welfare institutions and non-governmental organizations contracted by the MoSA, resulting in extensive overlaps and administrative waste.

The government developed in 2007 a Social Action Plan (SAP) to reduce poverty, improve social indicators, and achieve the Millennium Development Goals. The SAP contains a medium-term strategy to introduce safety net programs such as: i) cash transfers to the very poor households; ii) school feeding, books, stationery, and transportation facilities to students living in poor locations; and iii) free hospitalization for all households under the poverty line.

The MoSA, in conjunction with the World Bank, is now working on a National Targeting Program (NTP). One of the main goals of the NTP is to develop a credible and reliable database, enabling an objective assessment of households' welfare so as to more effectively target safety net programs. A pilot is now being conducted in three low-income districts, with the objective of extending it gradually to the national level. 


\section{Despite the likely slowdown}

in deposit growth, the authorities expect to meet the 2009 financing needs from the market. A peak in debt service swells the government's gross financing needs in 2009 to LL 21.9 trillion, of which the foreign currency share is LL 8.5 trillion (US\$5.6 billion). Nevertheless, the authorities believe that domestic commercial banks will be able to finance these needs through treasury bills and Eurobonds (of which banks are the main holders), even if there is little rollover by international

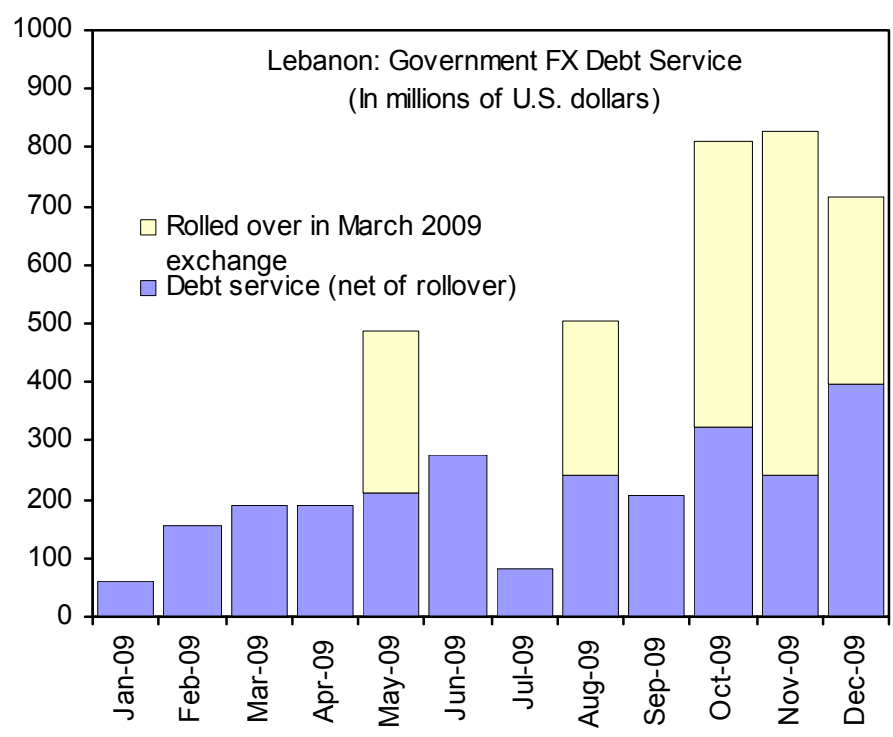
investors. The authorities were encouraged by the successful completion in March 2009 of an Eurobond exchange which rolled over $\$ 1.9$ billion in maturities coming due later in the year (implying a rollover rate of 83 percent) and provided new cash for around $\$ 440$ million, with

Lebanon: Gross Financing Needs and Sources, 2008-09

\begin{tabular}{lrr}
\hline & 2008 & 2009 \\
\hline \multicolumn{3}{c}{ (in billions of Lebanese pounds) } \\
Gross financing needs & 20,260 & 21,859 \\
Overall fiscal deficit & 4,300 & 5,791 \\
Amortization & 15,960 & 16,068 \\
& & \\
Gross financing sources & 20,260 & 21,859 \\
$\quad$ Domestic currency & 16,515 & 14,552 \\
Eurobond & 3,381 & 6,071 \\
$\quad$ Domestic banks & 1,453 & 5,710 \\
$\quad$ Other & 1,928 & 361 \\
Concessional borrowing & 364 & 1,235 \\
Memo items (in percent): & & \\
Eurobond rollover rate & 92 & 149 \\
Domestic banks & 61 & 238 \\
Other & 152 & 21 \\
\hline
\end{tabular}

yields ranging from 7.5-9 percent for the new instruments depending on maturity. The exchange should be sufficient to bridge the financing needs until after the June elections, when the authorities plan to issue new Eurobonds to roll over maturing instruments and raise new borrowing, provided that the latter is authorized by parliament through the budget law or separate legislation. Throughout the year, external financing will also be forthcoming from donors, mostly in the context of the Paris III commitments. In order to protect the foreign exchange buffer, the government will avoid to the extent possible relying on central bank financing.

16. The authorities are considering contingency plans in case financing difficulties materialize. A discussion of stress tests developed by staff highlighted that the authorities' financing plans are highly dependent on deposit growth, and underlined the importance of preparing contingency plans. Should deposit growth slow to critical levels, the authorities will consider a policy response that would include: (i) higher interest rates; (ii) a temporarily lower accumulation of international reserves; (iii) further fiscal adjustment, such as compression of discretionary spending, additional increases in excises and/or bringing forward the VAT hike now slated for 2010; and (iv) efforts to mobilize additional donor support. 


\section{Strengthening the Banking Sector}

17. The authorities are stepping up their vigilance over the banking sector. The authorities believe that the banking system is in a good position to address a stronger-than-expected fall in deposit growth, or a significant worsening in loan quality -in Lebanon or in the regional operations - under the stress of the slowdown in the real economy. Nevertheless, the BCC has strengthened reporting requirements on domestic and foreign operations, carried out stress tests for the banking system and intensified on-site inspections specifically aimed at assessing the impact of the global financial turbulence. To further increase the already high capitalization of banks, the BdL has recently recommended limiting dividend payments to 25 percent of 2008 profits. Finally, the BdL, in coordination with the government and the $\mathrm{BCC}$, has prepared draft legislation for the creation of the regulatory authority for financial markets, which are currently supervised jointly by the BdL and the BCC.

18. In the authorities' view, the current banking resolution framework provides for a flexible response capability. The authorities recently enacted a revised bank merger law, which enables the BdL to deal preemptively with troubled banks. The law, in line with past practice, is designed to prevent to the extent possible bank failures, relying on mergers and takeovers by sounder banks rather than outright bankruptcy. The authorities also developed plans to reform the deposit insurance fund, the coverage of which, at just over $\$ 3000$ per depositor, is clearly inadequate. However, given the advantage of maintaining regulatory stability at this time, they intend to proceed with this reform after international financial conditions improve.

\section{Medium-Term Plans to Tackle Vulnerabilities}

19. There is broad agreement across the political spectrum that reducing the high public debt-to-GDP ratio and launching structural reforms are the key medium-term priorities. The outcome of the June 2009 elections is uncertain. However, the authorities' view of the Paris III agenda as the anchor for medium-term plans is likely to be shared by any future government. On that basis, medium-term fiscal tightening would mainly rely on the already planned gradual increase in the VAT rate from 10 to 15 percent, the introduction of the Global Income Tax, and cuts in non-essential expenditures. Further savings would come from tackling the large losses at EdL—a key priority—since, despite the fall in international oil prices, current electricity tariffs still imply a significant untargeted subsidy, underscoring the need for a tariff revision. The authorities also see as a priority the launch of the privatization of the mobile phone providers as soon as market conditions allow, thus boosting private sector activity and reducing the debt.

\section{Timely and flexible disbursement of Paris III pledges is another important} element of the authorities' strategy. While progress has been made in the disbursement of these pledges, disbursements have fallen short of expectations partly because of political and security conditions and longer than expected negotiations. Furthermore, given the relatively 
insufficient share of budget support in the total, disbursements have not been fully aligned with the goal of debt reduction.

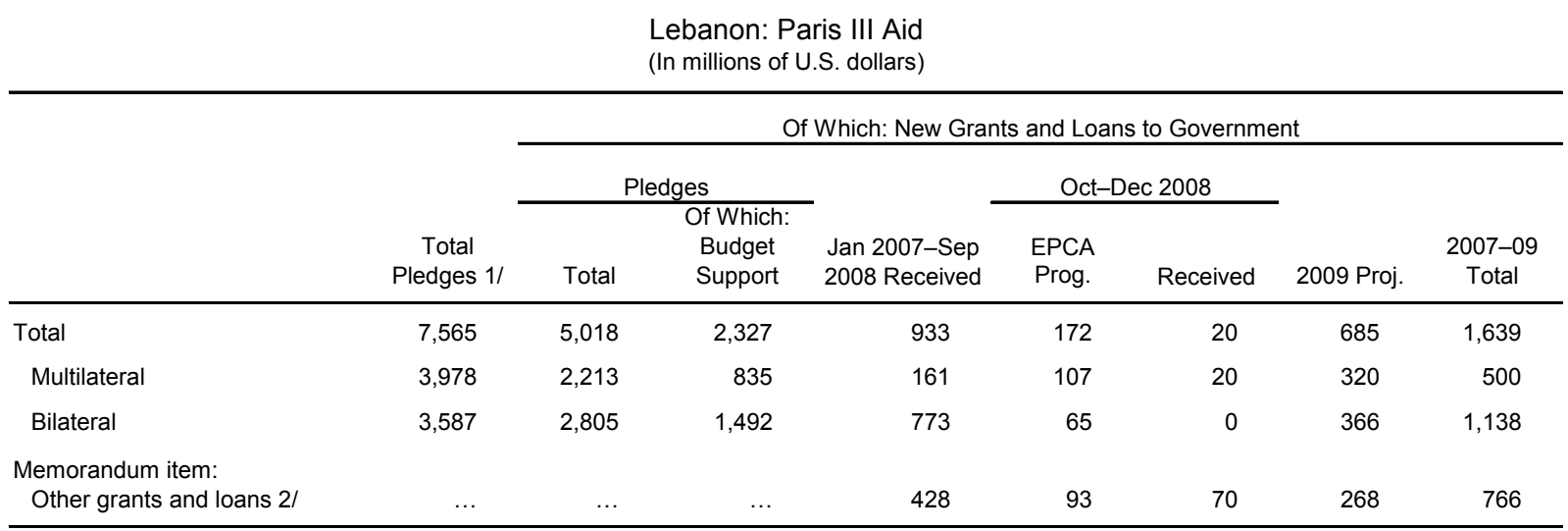

Sources: Lebanese authorities, and Fund staff estimates.

1/ Pledges for support to Lebanon through the government, the private sector, United Nations organizations and civil society organizations. 2/ Not Paris III-related: support related to reconstruction after the 2006 war with Israel, reconstruction of surrounding areas of the Nahr El-Bared refugee camp, and various project grants and loans.

21. Several structural fiscal reforms are under preparation. Parliament approved the tax procedure code at end 2008, even though several associated regulations are still pending. A cash management unit was legally created by end 2008 and is implementing a pilot on monthly payment forecasts with three line ministries. The draft Global Income Tax bill should be submitted to the Council of Ministers and Parliament in the coming months. The authorities are in the early stages of restructuring the tax administration. Finally, the Treasury Single Account legislation is under examination in parliament.

Lebanon: Projected Yield from the Authorities' Fiscal Measures: 2010-14

\begin{tabular}{|c|c|c|c|c|c|c|c|c|}
\hline & 2010 & 2011 & 2012 & 2013 & 2014 & Gain & $\begin{array}{l}\text { Technical } \\
\text { Risk 1/ }\end{array}$ & $\begin{array}{l}\text { Implementation } \\
\text { Risk 2/ }\end{array}$ \\
\hline & \multicolumn{6}{|c|}{ (In percent of GDP) } & & \\
\hline Fiscal measures & 4.5 & 0.6 & 0.2 & 1.6 & 0.0 & 6.9 & & \\
\hline Revenue & 1.6 & 0.5 & 0.2 & 1.6 & 0.0 & 3.9 & & \\
\hline Increase in the VAT rate (from 10 to 15 percent) & 0.8 & 0.0 & 0.0 & 1.5 & 0.0 & 2.2 & Medium & High \\
\hline Introduction of the global income tax & 0.3 & 0.3 & 0.2 & 0.0 & 0.0 & 0.8 & Medium & Medium \\
\hline Increase in gasoline excises to their pre-capping level & 0.3 & 0.2 & 0.0 & 0.0 & 0.0 & 0.6 & Low & High \\
\hline Taxation of seashore properties (penalties) & 0.3 & 0.0 & 0.0 & 0.0 & 0.0 & 0.3 & Low & Unknown \\
\hline Expenditure & 2.9 & 0.1 & 0.0 & 0.0 & 0.0 & 3.0 & & \\
\hline Cuts in non-essential spending & 0.1 & 0.1 & 0.0 & 0.0 & 0.0 & 0.2 & Low & Medium \\
\hline Reduction in EdL losses & 2.8 & 0.0 & 0.0 & 0.0 & 0.0 & 2.8 & Medium & High \\
\hline Other developments $3 /$ & 1.6 & 0.9 & -1.0 & 0.0 & -0.1 & 1.5 & & \\
\hline Revenue loss due to privatization & 2.0 & 1.2 & 0.0 & 0.0 & 0.0 & 3.2 & Medium & High \\
\hline WTO accession (costs) & 0.1 & 0.0 & 0.0 & 0.0 & 0.0 & 0.1 & n.a. & n.a. \\
\hline Other $4 /$ & -0.5 & -0.3 & -1.0 & 0.0 & 0.0 & -1.8 & n.a. & n.a. \\
\hline Change in primary balance (excluding grants) & 2.9 & -0.4 & 1.3 & 1.6 & 0.1 & 5.5 & n.a. & n.a. \\
\hline
\end{tabular}

Sources: IMF staff projections. Figures may not add up due to rounding

$1 /$ Refers to the technical risk (e.g., simulations based on inadequate data, etc.) in achieving the expected yield.

2/ Refers mainly to political risk.

$3 /$ Positive values indicate loss of revenue or higher spending.

4 / Includes increases in capital spending; and settlement of past NSSF dues. 


\section{Box 7. Lebanon: Shock Scenarios for Debt Sustainability Analysis}

Even with an ambitious debt reduction strategy, Lebanon will remain vulnerable to shocks for many years. With full implementation of the strategy, primary surpluses (excluding grants) could reach over 5 percent of GDP over the medium term, and with this, government debt could decline to around 136 percent of GDP by 2014. However, this scenario is ambitious, and substantial risks to the downside remain: higher interest rates, lower economic growth, or delays in policy implementation could imply a renewed increase in the debt-to-GDP ratio.

Panel 1: The baseline scenario_-implementation of Paris III reform measures.

Panel 2: A permanent increase in the real interest rate of 220 basis points (i.e., one-half standard deviation from its past distribution) relative to the baseline.

Panel 3: A permanent decrease in real GDP growth of 1.6 percentage points (i.e., one-half of the standard deviation from its past distribution).

Panel 4: Limited implementation of the fiscal reforms that would halve the yield from the fiscal reform package during 2010-14. This implies that the primary surplus would converge to about 3.0 percent of GDP in 2014 (baseline: 5.8 percent).

Panel 5: Failure to implement a fiscal consolidation process keeping a nil primary balance in 2009 and in the medium term; medium-term growth assumed one percentage point lower than in the baseline.

Panel 6: No privatization-since privatization essentially brings forward the income stream from the privatized companies, the scenarios with and without privatization converge to the same debt ratio in the long run. However, this abstracts from the negative impact that abandoning privatization plans would have on growth and, possibly, interest rates. 
Figure 1. Lebanon: Public Debt Sustainability, 2004-14 (Public debt in percent of GDP)

Panel 1: Baseline Scenario
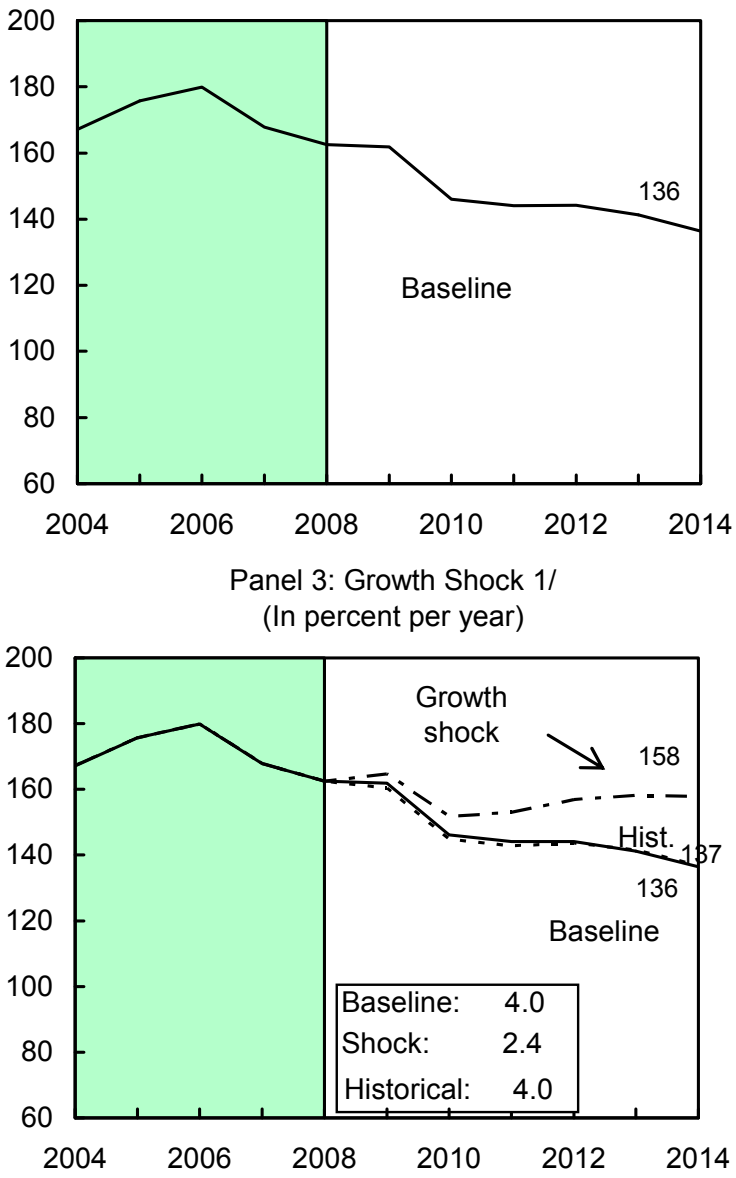

Panel 5: No Fiscal Consolidation 3/

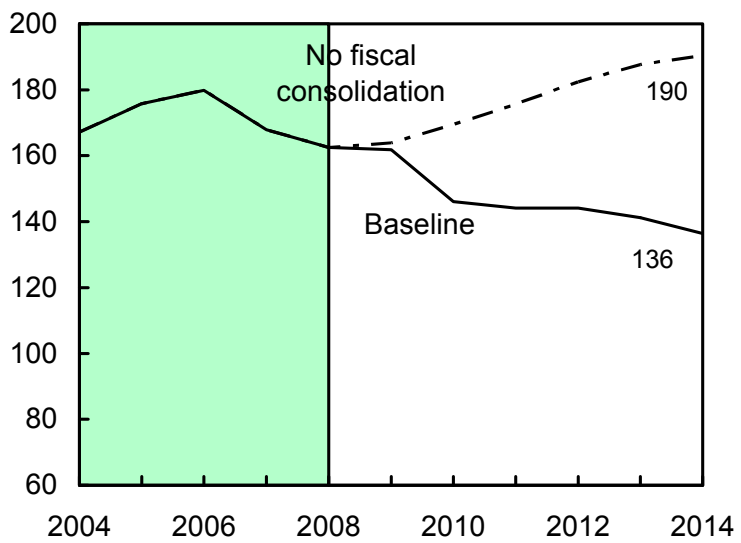

Panel 2: Real Interest Rate Shock 1/ (In percent)

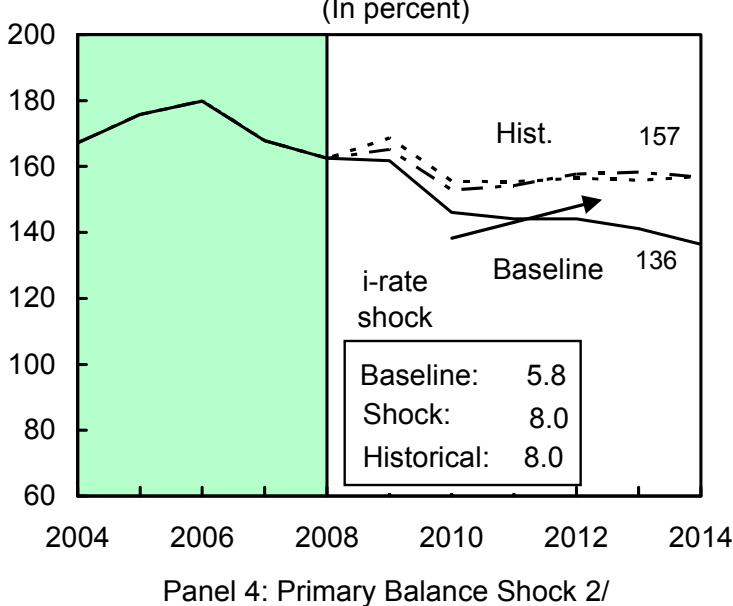

(In percent of GDP)

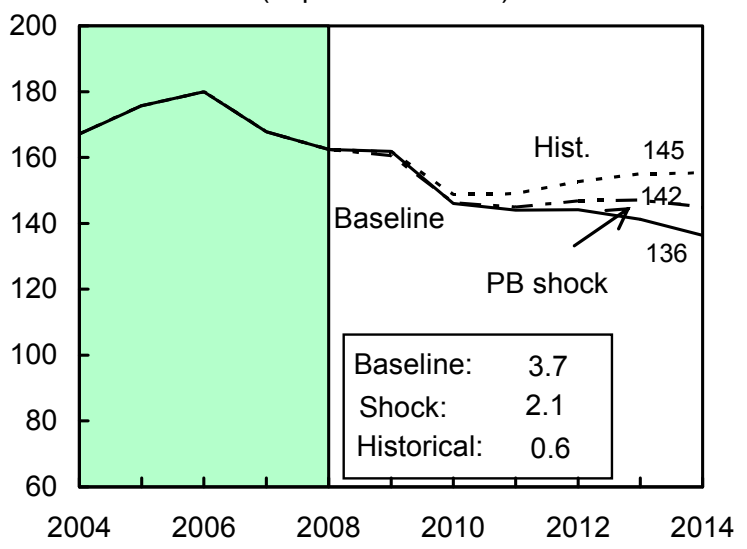

Sources: International Monetary Fund, country desk data, and staff estimates.

$1 /$ Growth and interest rate shocks are permanent one-half standard deviation shocks. Figures in the boxes represent average projections for the respective variables in the baseline scenario and shock scenario; historical refers to 10-year averages.

2/ The planned revenue and expenditures reforms generate less than half of the estimated yield of the baseline scenario. This leads to a primary surplus of 3 percent of GDP by 2014 .

3/ Nil primary balance in 2009 and in the medium term, no privatization, and medium term growth assumed one percentage point lower than in the baseline.

4/ No privatization in the projected period. Assumes no adverse dynamic impact of no privatization. 
22. The authorities recognize the need to strengthen the BdL's balance sheet over the medium term. The planned fiscal consolidation, together with de-dollarization, will allow a lowering of interest rates and help strengthen the BdL's balance sheet. Privatization of the assets held by the central bank once market conditions permit will also help its financial balance, while contributing to the government's growth agenda.

\section{OTHER ISSUES}

\section{The mission discussed technical assistance (TA) needs and the new charging} policy. The mission stressed that the Fund stands ready to provide assistance particularly in the areas of public financial management, tax administration, banking regulation/supervision, Anti-Money Laundering (AML) and Combating the Financing of Terrorism (CFT), central bank reforms, and statistical issues (below). The authorities expressed interest in a possible FSAP update in the course of 2009.

24. The authorities are reinforcing their AML/CFT framework. In order to implement the Special Recommendations of the Financial Action Task Force (FATF), the authorities are improving the existing AML legislation, which would now also cover CFT. The amendments increase the powers of Lebanon's Special Investigative Commission, an independent financial intelligence unit with judicial status charged with implementing AML, and stiffen the penalties for AML breaches. Lebanon is currently undergoing an AML/CFT assessment by MENAFATF (a FATF-style regional body).

\section{The authorities are improving their statistical systems, but significant data} problems remain. With support from INSEE, they are improving the quality of GDP data and the timeliness of their dissemination, recently publishing national accounts to 2007. In 2008, they have also launched an improved CPI index with the help of TA from the Fund. However, statistical provision in other areas (balance of payments, employment, wage and social indicators) remains seriously deficient. The authorities agree that improvement in statistical systems are essential to support economic analysis and policy making, and the next government is expected to increase investment in statistical resources.

\section{Staff Appraisal}

26. Achievements: The resilience of the Lebanese economy in the midst of the ongoing global crisis demonstrates the benefits of macroeconomic policy discipline under the EPCA and strict oversight on the financial sector. International reserves have hit a record high. The banking sector has not come under stress. Lebanese Eurobonds have outperformed the emerging market average. So far, there are not clear signs of slowdown in economic activity. Thus, Lebanon has been insulated from the global deleveraging process that has hit those financial systems flushed with high-risk structured products or with a risky funding structure. 
27. The EPCA: The quarterly monitoring framework set up in the context of the two drawings under EPCA has proved to be an effective tool to support the authorities' efforts to preserve macroeconomic and financial stability despite the difficult domestic political conditions and the increasingly challenging external environment. The authorities deserve merit for having met all quantitative targets with substantial margins. However, while slippages in the structural reform agenda reflect the domestic and international environment, a swift implementation of the reform agenda after the elections is necessary to make inroads toward reducing Lebanon's vulnerabilities.

28. Challenges and risks: These successes do not leave scope for complacency. The deepening global recession and the dysfunctional international credit markets make it even more urgent for Lebanon to address its still high vulnerabilities. Short-term policies will need to be geared toward reducing the possible impact from the downward risks to the outlook by safeguarding the recent progress toward debt sustainability and a stronger external position. The possible confluence of domestic political uncertainty, regional instability, and the faltering global economic conditions constitute the main risk. Therefore, both monetary and fiscal policies need to be prudent, and financial supervision vigilant. Proactive contingency planning should also top the policy agenda.

29. Monetary and exchange rate policies: Monetary policy needs to continue to safeguard the peg, a prerequisite for financial stability given the large currency mismatches of the government, corporate, and household sectors, and the government's high debt and debt service obligations in foreign currency. Staff estimates suggest that the real exchange rate remains broadly in line with fundamentals. Given the various risks, staff agrees with the authorities that there is not much scope for lowering interest rates in the near term. This cautious approach should last at least until the elections to attract deposit inflows, foster dedollarization, and buttress the international-reserve buffer to insure against a confidence backlash.

30. Fiscal stance: Lebanon's high debt level does not leave scope for countercyclical action. The moderate loosening in the fiscal stance in the 2009 draft budget will bring to a halt the recent decline in the debt-to-GDP ratio, substantially widen the government overall deficit, and could complicate government financing in case downside risks to the scenario materialize. Thus, staff believe that a primary surplus of close to 2 percent of GDP would be desirable, to preserve the trend toward debt reduction and maintain an unchanged overall financing requirements in 2009. While the current political circumstances, the likely slowdown in economic growth, and the soaring wage bill could make it difficult to attain this target, staff believe that strict expenditure restraint in the run up to the elections and the implementation of the Paris III fiscal policy package thereafter should aim at achieving a significantly higher primary balance than envisaged by the draft budget. Staff, therefore, recommends that any revenue over-performance be saved and any shortfall in capital spending be preserved. 
31. Fiscal rigidities: The spending increase for wages and salaries is likely to absorb the fiscal space created by the drop in international oil prices and the welcome reintroduction of the gasoline excise in 2009. While the increase reflects in part the realization of contingent liabilities and unsustainable wage compression in the past, it adds a substantial budgetary rigidity and raises fiscal risk. Much of this increase will be permanent, whereas part of the fiscal space gained through reduced transfers to EdL depends on highly volatile oil prices. A targeted redirecting of expenditures would help meet the authorities' social objectives much more efficiently than generalized wage increases. Careful phasing of expenditures is also needed to meet the fiscal targets under EPCA.

32. Contingency planning for government financing: The seizure in international capital markets and wider fiscal deficit will increase the burden on domestic banks to provide government financing, at a time of a slowdown in deposit growth. Staff agrees that under prudent assumptions banks should be able to provide sufficient financing, even in the absence of funding from international investors. Nevertheless, contingency planning remains essential to face the risk that election-related political uncertainty and a prolonged global recession could translate into a more substantial drop in deposit inflows. Staff and the authorities agree that the appropriate response would include a combination of fiscal adjustment, a lower pace of reserve accumulation, higher interest rates, and possibly additional use of Fund resources.

33. Banking sector: The specific funding and asset structure of banks, backed by effective banking supervision and regulation, have shielded the Lebanese banking system from exposure to global liquidity shortages, structured products, and real estate. Looking forward, continued vigilance is needed, since banks may still be affected by the global financial crisis, and the slowdown in growth in Lebanon and in the region could raise nonperforming loans, although provisioning and capitalization remain sizeable. The authorities' heightened focus on the bank resolution framework, including through the implementation of the merger law, is welcome, as it would help address potential negative effects of the global financial crisis on Lebanese banks.

34. The Paris III agenda: The proximity of the general elections and the global financial crisis has delayed implementation of key structural reforms that supported the debt reduction objectives of the Paris III agenda. There are three top priorities. First, the energy sector absorbs an unacceptably high amount of budgetary resources, and dampens Lebanon's growth and productivity potential because of its inefficiencies. Despite the drop in international prices, current tariffs imply a significant untargeted subsidy that needs to be eliminated. Second, proceeding with the planned privatization of the mobile phone providers as soon as market conditions allow could go a long way toward promoting private sector growth and reducing debt-related vulnerabilities. Third, a gradual increase in the VAT rate to 15 percent would be needed to bring primary surpluses to levels that would approach debt sustainability over the medium term. Implementing these measures may prove to be difficult, but remains necessary to move towards sustainability. However, even under full 
implementation of the Paris III agenda, vulnerabilities would decline only gradually and significant risks would persist for many years.

35. Donor disbursements: Timely and flexible disbursement of the Paris III pledges is a key component of the debt reduction strategy. Unfortunately, disbursements have fallen short of expectations. Progress on the Paris III agenda, on which much of the pledges were conditioned, should help accelerate disbursements. Staff supports the authorities' request that donors provide as much budgetary support as possible.

36. BdL balance sheet: The decline in international interest rates has highlighted the cost of maintaining high domestic interest rates to attract inflows and increase reserves. Action is needed to strengthen the BdL balance sheet. Staff believes the BdL should consider shifting from issuing higher-yielding securities toward using its large T-bill portfolio as the main tool for sterilizing excess liquidity. This would lower sterilization costs for the BdL and support fiscal discipline by making the cost of government financing more transparent. Over time a stronger fiscal position and reduced dollarization will also help strengthen the BdL balance sheet.

37. Data issues: The authorities have improved significantly GDP and CPI statistics. However, data insufficiencies still hamper the analysis of real and external sector developments. High-level commitment by the next government and by the BdL is needed to address these shortcomings through a comprehensive strategy to strengthen statistics.

38. It is proposed that the next Article IV consultation be held on the standard 12-month cycle. 
Table 1. Lebanon: Selected Economic Indicators, 2006-14

\begin{tabular}{|c|c|c|c|c|c|c|c|c|c|}
\hline & $\begin{array}{r}2006 \\
\text { Act. }\end{array}$ & $\begin{array}{r}2007 \\
\text { Act. }\end{array}$ & $\begin{array}{r}2008 \\
\text { Est. }\end{array}$ & $\begin{array}{l}2009 \\
\text { Proj. }\end{array}$ & $\begin{array}{l}2010 \\
\text { Proj. }\end{array}$ & $\begin{array}{l}2011 \\
\text { Proj. }\end{array}$ & $\begin{array}{l}2012 \\
\text { Proj. }\end{array}$ & $\begin{array}{l}2013 \\
\text { Proj. }\end{array}$ & $\begin{array}{l}2014 \\
\text { Proj. }\end{array}$ \\
\hline Output and prices & \multicolumn{8}{|c|}{ (Annual percentage change) } & \\
\hline Real GDP (market price) & 0.6 & 7.5 & 8.5 & 3.0 & 4.0 & 4.0 & 4.5 & 4.5 & 4.5 \\
\hline GDP deflator & 2.0 & 3.8 & 6.5 & 5.0 & 2.0 & 3.0 & 1.9 & 2.1 & 2.2 \\
\hline Consumer prices (end-of- period) & 7.2 & 6.0 & 6.4 & 3.9 & 2.9 & 2.6 & 2.6 & 2.1 & 2.2 \\
\hline Consumer prices (period average) & 5.6 & 4.1 & 10.8 & 3.6 & 2.1 & 3.2 & 2.0 & 2.2 & 2.2 \\
\hline Investment and saving & \multicolumn{8}{|c|}{ (In percent of GDP) } & \\
\hline Gross capital formation & 22.7 & 27.4 & 21.4 & 21.1 & 23.5 & 20.5 & 22.5 & 32.1 & 29.8 \\
\hline Government & 2.5 & 2.4 & 1.7 & 2.9 & 2.7 & 2.4 & 2.5 & 2.6 & 2.6 \\
\hline Nongovernment & 20.2 & 25.0 & 19.8 & 18.2 & 20.8 & 18.0 & 20.0 & 29.5 & 27.2 \\
\hline Gross national savings & 17.1 & 20.3 & 10.1 & 10.5 & 13.5 & 10.4 & 12.9 & 23.2 & 21.9 \\
\hline Government & -7.8 & -8.5 & -8.2 & -9.4 & -7.0 & -8.2 & -6.2 & -3.4 & -1.4 \\
\hline Nongovernment & 24.9 & 28.8 & 18.3 & 20.0 & 20.5 & 18.7 & 19.1 & 26.7 & 23.3 \\
\hline Public finances (cash basis) & \multicolumn{8}{|c|}{ (In percent of GDP) } & \\
\hline Revenue (including grants) & 25.1 & 24.4 & 24.8 & 25.2 & 24.4 & 23.4 & 23.8 & 25.3 & 25.3 \\
\hline of which: grants & 2.9 & 1.4 & 0.9 & 0.4 & 0.4 & 0.2 & 0.2 & 0.3 & 0.3 \\
\hline Expenditure & 35.5 & 35.3 & 34.6 & 37.5 & 34.2 & 34.0 & 32.5 & 31.4 & 29.3 \\
\hline Budget balance (including grants) & -10.4 & -10.9 & -9.9 & -12.3 & -9.8 & -10.7 & -8.7 & -6.1 & -4.0 \\
\hline Primary balance (including grants) & 2.6 & 1.7 & 1.6 & 0.5 & 3.3 & 2.8 & 4.1 & 5.7 & 5.8 \\
\hline Primary balance (excluding grants) & -0.4 & 0.3 & 0.7 & 0.0 & 3.0 & 2.6 & 3.8 & 5.4 & 5.5 \\
\hline Total government debt & 180 & 168 & 162 & 162 & 146 & 144 & 144 & 141 & 136 \\
\hline Monetary sector & \multicolumn{8}{|c|}{ (Annual percentage change, unless otherwise indicated) } & \\
\hline Broad money $1 /$ & 6.4 & 10.9 & 15.5 & 10.0 & 10.0 & 9.0 & 9.0 & 9.0 & 9.0 \\
\hline Velocity of broad money (level) & 0.4 & 0.4 & 0.4 & 0.4 & 0.3 & 0.3 & 0.3 & 0.3 & 0.3 \\
\hline External sector & \multicolumn{8}{|c|}{ (In percent of GDP, unless otherwise indicated) } & \\
\hline Current account including official transfers & -5.6 & -7.1 & -11.4 & -10.5 & -10.0 & -10.0 & -9.6 & -8.9 & -7.9 \\
\hline Total external debt & 199 & 194 & 191 & 182 & 181 & 186 & 194 & 194 & 194 \\
\hline Gross reserves (in millions of U.S. dollars) & 11,353 & 11,496 & 18,769 & 20,866 & 24,312 & 25,391 & 27,148 & 29,322 & 32,376 \\
\hline In months of next year imports of goods and services & 7 & 5 & 8 & 8 & 9 & 9 & 9 & 9 & 9 \\
\hline In percent of short-term external debt $2 /$ & 32 & 30 & 40 & 44 & 47 & 44 & 42 & 42 & 44 \\
\hline In percent of banking system foreign currency deposits & 30 & 27 & 43 & 47 & 50 & 48 & 47 & 46 & 47 \\
\hline In percent of total banking system deposits & 21.9 & 19.7 & 28.2 & 28.4 & 30.1 & 28.8 & 28.3 & 28.0 & 28.3 \\
\hline \multicolumn{10}{|l|}{ Memorandum item: } \\
\hline Nominal GDP (in billions of U.S. dollars) & 22.4 & 25.0 & 28.9 & 31.3 & 33.2 & 35.6 & 37.9 & 40.4 & 43.1 \\
\hline
\end{tabular}

Sources: Lebanese authorities; and Fund staff estimates.

$1 /$ Defined as currency in circulation plus resident and non-resident deposits.

2/ Short-term debt on a remaining maturity basis. 
Table 2. Lebanon: Central Government Overall Deficit and Financing: 2006-14

\begin{tabular}{|c|c|c|c|c|c|c|c|c|c|}
\hline & $\begin{array}{l}2006 \\
\text { Year } \\
\text { Act. }\end{array}$ & $\begin{array}{l}2007 \\
\text { Year } \\
\text { Act. }\end{array}$ & $\begin{array}{l}2008 \\
\text { Year } \\
\text { Prel. }\end{array}$ & $\begin{array}{l}2009 \\
\text { Year } \\
\text { Proj. }\end{array}$ & $\begin{array}{l}2010 \\
\text { Year } \\
\text { Proj. }\end{array}$ & $\begin{array}{l}2011 \\
\text { Year } \\
\text { Proj. }\end{array}$ & $\begin{array}{l}2012 \\
\text { Year } \\
\text { Proj. }\end{array}$ & $\begin{array}{l}2013 \\
\text { Year } \\
\text { Proj. }\end{array}$ & $\begin{array}{l}2014 \\
\text { Year } \\
\text { Proj. }\end{array}$ \\
\hline \multicolumn{10}{|c|}{ (In billions of Lebanese pounds, unless otherwise indicated) } \\
\hline Revenue and grants & 8,486 & 9,221 & 10,799 & 11,912 & 12,217 & 12,521 & 13,588 & 15,434 & 16,443 \\
\hline Revenue & 7,490 & 8,696 & 10,412 & 11,711 & 12,019 & 12,401 & 13,452 & 15,277 & 16,261 \\
\hline Tax revenue & 4,922 & 5,581 & 7,241 & 8,239 & 9,215 & 10,209 & 11,113 & 12,780 & 13,591 \\
\hline Taxes on income and profits & 1,166 & 1,307 & 1,622 & 1,894 & 2,074 & 2,559 & 3,031 & 3,249 & 3,456 \\
\hline Taxes on property & 579 & 532 & 786 & 702 & 878 & 940 & 1,001 & 1,068 & 1,140 \\
\hline Taxes on domestic goods and services & 1,844 & 2,224 & 2,895 & 3,082 & 3,604 & 3,838 & 4,071 & 5,282 & 5,632 \\
\hline Of which: VAT revenues & 1,659 & 2,003 & 2,584 & 2,758 & 3,304 & 3,517 & 3,728 & 4,917 & 5,242 \\
\hline Taxes on international trade $1 /$ & 1,074 & 1,247 & 1,588 & 2,193 & 2,269 & 2,454 & 2,565 & 2,705 & 2,855 \\
\hline Other taxes & 259 & 271 & 350 & 368 & 390 & 418 & 445 & 475 & 507 \\
\hline Nontax revenue & 2,219 & 2,648 & 2,613 & 2,999 & 2,302 & 1,654 & 1,778 & 1,911 & 2,058 \\
\hline Entrepreneurial and property income & 1,702 & 2,141 & 2,028 & 2,407 & 1,535 & 982 & 1,062 & 1,147 & 1,242 \\
\hline Administrative fees and charges & 426 & 421 & 484 & 474 & 503 & 539 & 573 & 612 & 653 \\
\hline Other nontax revenue & 91 & 86 & 101 & 118 & 264 & 134 & 143 & 152 & 163 \\
\hline Other treasury revenue & 349 & 467 & 558 & 473 & 502 & 537 & 561 & 586 & 613 \\
\hline Grants & 996 & 525 & 387 & 201 & 198 & 121 & 136 & 157 & 182 \\
\hline Total expenditures & 12,289 & 13,291 & 15,159 & 17703 & 17106 & 18253 & 18548 & 19126 & 19067 \\
\hline Current primary expenditure & 7,051 & 7,657 & 9,451 & 10,355 & 9,168 & 9,708 & 9,821 & 10,385 & 10,988 \\
\hline Wages, salaries and pensions & 3,307 & 3,583 & 4,027 & 5,340 & 5,653 & 6,043 & 6,018 & 6,431 & 6,875 \\
\hline Transfers to EDL 2/ & 1,137 & 1,182 & 2,315 & 1,754 & 465 & 506 & 537 & 573 & 612 \\
\hline Other current & 2,607 & 2,892 & 3,109 & 3,261 & 3,050 & 3,159 & 3,266 & 3,381 & 3,501 \\
\hline Materials and supplies & 140 & 198 & 273 & 267 & 273 & 281 & 287 & 293 & 300 \\
\hline External services & 87 & 84 & 106 & 112 & 114 & 118 & 120 & 123 & 126 \\
\hline Transfers $3 / 4 /$ & 878 & 828 & 657 & 853 & 799 & 828 & 855 & 886 & 919 \\
\hline Other & 507 & 952 & 746 & 825 & 586 & 603 & 615 & 627 & 640 \\
\hline Of which: housing compensation & 136 & 612 & 282 & 244 & 0 & 0 & 0 & 0 & 1 \\
\hline Other treasury outflows $5 /$ & 995 & 830 & 1,327 & 1,204 & 1,278 & 1,329 & 1,388 & 1,451 & 1,516 \\
\hline Interest payments & 4,381 & 4,732 & 4,979 & 6,003 & 6,565 & 7,233 & 7,284 & 7,140 & 6,368 \\
\hline Domestic currency debt & 2,368 & 2,515 & 2,847 & 3,648 & 4,268 & 4,766 & 4,844 & 5,101 & 4,988 \\
\hline Foreign currency debt & 2,013 & 2,217 & 2,132 & 2,355 & 2,297 & 2,467 & 2,440 & 2,039 & 1,380 \\
\hline Capital expenditure & 857 & 903 & 729 & 1,345 & 1,373 & 1,311 & 1,444 & 1,602 & 1,712 \\
\hline Domestically financed & 446 & 442 & 425 & 895 & 900 & 805 & 907 & 1,029 & 1,100 \\
\hline Foreign financed & 411 & 461 & 304 & 450 & 473 & 506 & 537 & 573 & 612 \\
\hline Overall balance (checks issued) & $-3,803$ & $-4,070$ & $-4,360$ & $-5,791$ & $-4,889$ & $-5,731$ & $-4,960$ & $-3,692$ & $-2,624$ \\
\hline Primary balance (checks issued) & 578 & 662 & 619 & 212 & 1,675 & 1,502 & 2,324 & 3,448 & 3,743 \\
\hline Statistical discrepancy/float & 293 & -34 & 60 & 0 & 0 & 0 & 0 & 0 & 0 \\
\hline Overall balance (cash basis) & $-3,510$ & $-4,104$ & $-4,300$ & $-5,791$ & $-4,889$ & $-5,731$ & $-4,960$ & $-3,692$ & $-2,624$ \\
\hline Primary balance (cash basis) & 871 & 627 & 679 & 212 & 1,675 & 1,502 & 2,324 & 3,448 & 3,743 \\
\hline Net financing & 3,510 & 4,104 & 4,300 & 5,791 & 4,889 & 5,731 & 4,960 & 3,692 & 2,624 \\
\hline Banking system & 1,935 & $-1,173$ & 3,232 & 6,596 & $-3,829$ & 3,431 & 4,203 & 3,280 & 2,762 \\
\hline Deposits & 1,022 & -511 & $-3,034$ & 300 & -50 & -50 & -50 & -50 & -50 \\
\hline Treasury Bills & 267 & -141 & 7,210 & 2,981 & 149 & 4,568 & 4,476 & 4,609 & 2,886 \\
\hline Eurobonds & 646 & -521 & -944 & 3,316 & $-3,929$ & $-1,087$ & -223 & $-1,279$ & -74 \\
\hline Government institutions & 867 & 1,483 & 266 & 472 & 401 & 429 & 457 & 487 & 520 \\
\hline Other creditors & 1,094 & 1,728 & 987 & $-1,277$ & 146 & 215 & 300 & -75 & -658 \\
\hline Tbills & -63 & -138 & 166 & -579 & 2,191 & 643 & 593 & 594 & -631 \\
\hline Eurobonds & 1,052 & 1,179 & 662 & $-1,333$ & $-1,700$ & -470 & -96 & -553 & -32 \\
\hline Concessional Loans & 105 & 686 & 159 & 634 & 73 & 43 & -196 & -116 & 6 \\
\hline Foreign Bonds & 0 & 0 & 0 & 0 & -419 & 0 & 0 & 0 & -1 \\
\hline Net change in arrears & 0 & 0 & 0 & 0 & 0 & 0 & 0 & 0 & 0 \\
\hline Exceptional financing $6 /$ & 0 & 2,380 & 0 & 0 & 8,172 & 1,657 & 0 & 0 & 0 \\
\hline Change in accrued interest & -196 & -45 & -267 & 0 & 0 & 0 & 0 & 0 & 0 \\
\hline Valuation adjustment & -190 & -268 & 82 & 0 & 0 & 0 & 0 & 0 & 0 \\
\hline \multicolumn{10}{|l|}{ Memorandum items: } \\
\hline Primary balance on a checks issued basis (excluding grants) & -418 & 137 & 232 & 11 & 1,478 & 1,381 & 2,188 & 3,291 & 3,562 \\
\hline Total government debt & 60,851 & 63,364 & 70,874 & 76,365 & 73,132 & 77,256 & 82,267 & 86,009 & 88,683 \\
\hline Of which: foreign denominated debt & 30,647 & 31,991 & 31,868 & 34,485 & 28,511 & 26,996 & 26,480 & 24,532 & 24,431 \\
\hline
\end{tabular}

Sources: Lebanese authorities; and Fund staff estimates and calculations.

$1 /$ Includes domestic excises, which are collected at customs and are classified as taxes on international trade.

2/ Excludes principal and interest payments paid on behalf of EdL.

3/ From 2005 onward includes additional transfers to the social security funds (NSSF) to clear the stock of arrears.

4/ Includes \$275 million for telecom settlements (2006 and 2007).

$5 /$ Includes transfers to municipalities.

6/ Debt cancellation and Banque du Liban revaluation of gold in 2007 and projected privatization proceeds in 2010-11. 
Table 3. Lebanon: Central Government Overall Deficit and Financing: 2006-14

\begin{tabular}{|c|c|c|c|c|c|c|c|c|c|}
\hline & $\begin{array}{l}2006 \\
\text { Year } \\
\text { Act. }\end{array}$ & $\begin{array}{l}2007 \\
\text { Year } \\
\text { Act. }\end{array}$ & $\begin{array}{l}2008 \\
\text { Year } \\
\text { Prel. }\end{array}$ & $\begin{array}{l}2009 \\
\text { Year } \\
\text { Proj. }\end{array}$ & $\begin{array}{l}2010 \\
\text { Year } \\
\text { Proj. }\end{array}$ & $\begin{array}{l}2011 \\
\text { Year } \\
\text { Proj. }\end{array}$ & $\begin{array}{l}2012 \\
\text { Year } \\
\text { Proj. }\end{array}$ & $\begin{array}{l}2013 \\
\text { Year } \\
\text { Proj. }\end{array}$ & $\begin{array}{l}2014 \\
\text { Year } \\
\text { Proj. }\end{array}$ \\
\hline \multicolumn{10}{|c|}{ (In percent of GDP, unless otherwise indicated) } \\
\hline Revenue and grants & 25.1 & 24.4 & 24.8 & 25.2 & 24.4 & 23.4 & 23.8 & 25.3 & 25.3 \\
\hline Revenue & 22.1 & 23.0 & 23.9 & 24.8 & 24.0 & 23.1 & 23.6 & 25.1 & 25.0 \\
\hline Tax revenue & 14.6 & 14.8 & 16.6 & 17.5 & 18.4 & 19.0 & 19.5 & 21.0 & 20.9 \\
\hline Taxes on income and profits & 3.4 & 3.5 & 3.7 & 4.0 & 4.1 & 4.8 & 5.3 & 5.3 & 5.3 \\
\hline Taxes on property & 1.7 & 1.4 & 1.8 & 1.5 & 1.8 & 1.8 & 1.8 & 1.8 & 1.8 \\
\hline Taxes on domestic goods and services & 5.5 & 5.9 & 6.6 & 6.5 & 7.2 & 7.2 & 7.1 & 8.7 & 8.7 \\
\hline Of which: VAT revenues & 4.9 & 5.3 & 5.9 & 5.8 & 6.6 & 6.6 & 6.5 & 8.1 & 8.1 \\
\hline Taxes on international trade $1 /$ & 3.2 & 3.3 & 3.6 & 4.6 & 4.5 & 4.6 & 4.5 & 4.4 & 4.4 \\
\hline Other taxes & 0.8 & 0.7 & 0.8 & 0.8 & 0.8 & 0.8 & 0.8 & 0.8 & 0.8 \\
\hline Nontax revenue & 6.6 & 7.0 & 6.0 & 6.4 & 4.6 & 3.1 & 3.1 & 3.1 & 3.2 \\
\hline Entrepreneurial and property income & 5.0 & 5.7 & 4.6 & 5.1 & 3.1 & 1.8 & 1.9 & 1.9 & 1.9 \\
\hline Administrative fees and charges & 1.3 & 1.1 & 1.1 & 1.0 & 1.0 & 1.0 & 1.0 & 1.0 & 1.0 \\
\hline Other nontax revenue & 0.3 & 0.2 & 0.2 & 0.3 & 0.5 & 0.3 & 0.3 & 0.3 & 0.3 \\
\hline Other treasury revenue & 1.0 & 1.2 & 1.3 & 1.0 & 1.0 & 1.0 & 1.0 & 1.0 & 0.9 \\
\hline Grants & 2.9 & 1.4 & 0.9 & 0.4 & 0.4 & 0.2 & 0.2 & 0.3 & 0.3 \\
\hline Total expenditures & 36.3 & 35.2 & 34.7 & 37.5 & 34.2 & 34.0 & 32.5 & 31.4 & 29.3 \\
\hline Current primary expenditure & 20.8 & 20.3 & 21.7 & 21.9 & 18.3 & 18.1 & 17.2 & 17.0 & 16.9 \\
\hline Wages, salaries and pensions & 9.8 & 9.5 & 9.2 & 11.3 & 11.3 & 11.3 & 10.5 & 10.6 & 10.6 \\
\hline Transfers to EDL 2/ & 3.4 & 3.1 & 5.3 & 3.7 & 0.9 & 0.9 & 0.9 & 0.9 & 0.9 \\
\hline Other current & 7.7 & 7.7 & 7.1 & 6.9 & 6.1 & 5.9 & 5.7 & 5.6 & 5.4 \\
\hline Materials and supplies & 0.4 & 0.5 & 0.6 & 0.6 & 0.5 & 0.5 & 0.5 & 0.5 & 0.5 \\
\hline External services & 0.3 & 0.2 & 0.2 & 0.2 & 0.2 & 0.2 & 0.2 & 0.2 & 0.2 \\
\hline Transfers $3 / 4 /$ & 2.6 & 2.2 & 1.5 & 1.8 & 1.6 & 1.5 & 1.5 & 1.5 & 1.4 \\
\hline Other & 1.5 & 2.5 & 1.7 & 1.7 & 1.2 & 1.1 & 1.1 & 1.0 & 1.0 \\
\hline Of which: housing compensation & 0.4 & 1.6 & 0.6 & 0.5 & 0.0 & 0.0 & 0.0 & 0.0 & 0.0 \\
\hline Other treasury outflows $5 /$ & 2.9 & 2.2 & 3.0 & 2.6 & 2.6 & 2.5 & 2.4 & 2.4 & 2.3 \\
\hline Interest payments & 13.0 & 12.5 & 11.4 & 12.7 & 13.1 & 13.5 & 12.8 & 11.7 & 9.8 \\
\hline Domestic currency debt & 7.0 & 6.7 & 6.5 & 7.7 & 8.5 & 8.9 & 8.5 & 8.4 & 7.7 \\
\hline Foreign currency debt & 6.0 & 5.9 & 4.9 & 5.0 & 4.6 & 4.6 & 4.3 & 3.3 & 2.1 \\
\hline Capital expenditure & 2.5 & 2.4 & 1.7 & 2.9 & 2.7 & 2.4 & 2.5 & 2.6 & 2.6 \\
\hline Domestically financed & 1.3 & 1.2 & 1.0 & 1.9 & 1.8 & 1.5 & 1.6 & 1.7 & 1.7 \\
\hline Foreign financed & 1.2 & 1.2 & 0.7 & 1.0 & 0.9 & 0.9 & 0.9 & 0.9 & 0.9 \\
\hline Overall balance (checks issued) & -11.2 & -10.8 & -10.0 & -12.3 & -9.8 & -10.7 & -8.7 & -6.1 & -4.0 \\
\hline Primary balance (checks issued) & 1.7 & 1.8 & 1.4 & 0.5 & 3.3 & 2.8 & 4.1 & 5.7 & 5.8 \\
\hline Statistical discrepancy/float & 0.9 & -0.1 & 0.1 & 0.0 & 0.0 & 0.0 & 0.0 & 0.0 & 0.0 \\
\hline Overall balance (cash basis) & -10.4 & -10.9 & -9.9 & -12.3 & -9.8 & -10.7 & -8.7 & -6.1 & -4.0 \\
\hline Primary balance (cash basis) & 2.6 & 1.7 & 1.6 & 0.5 & 3.3 & 2.8 & 4.1 & 5.7 & 5.8 \\
\hline Net financing & 10.4 & 10.9 & 9.9 & 12.3 & 9.8 & 10.7 & 8.7 & 6.1 & 4.0 \\
\hline Banking system & 5.7 & -3.1 & 7.4 & 14.0 & -7.6 & 6.4 & 7.4 & 5.4 & 4.2 \\
\hline Government institutions & 2.6 & 3.9 & 0.6 & 1.0 & 0.8 & 0.8 & 0.8 & 0.8 & 0.8 \\
\hline Other creditors & 3.2 & 4.6 & 2.3 & -2.7 & 0.3 & 0.4 & 0.5 & -0.1 & -1.0 \\
\hline Net change in arrears & 0.0 & 0.0 & 0.0 & 0.0 & 0.0 & 0.0 & 0.0 & 0.0 & 0.0 \\
\hline Exceptional financing 6/ & 0.0 & 6.3 & 0.0 & 0.0 & 16.3 & 3.1 & 0.0 & 0.0 & 0.0 \\
\hline Change in accrued interest & -0.6 & -0.1 & -0.6 & 0.0 & 0.0 & 0.0 & 0.0 & 0.0 & 0.0 \\
\hline Valuation adjustment & -0.6 & -0.7 & 0.2 & 0.0 & 0.0 & 0.0 & 0.0 & 0.0 & 0.0 \\
\hline \multicolumn{10}{|l|}{ Memorandum items: } \\
\hline Primary balance on a checks issued basis (excluding grants) & -1.2 & 0.4 & 0.5 & 0.0 & 3.0 & 2.6 & 3.8 & 5.4 & 5.5 \\
\hline Nominal GDP (Annual and in billions of LL) & 33,824 & 37,754 & 43,626 & 47,181 & 50,065 & 53,615 & 57,074 & 60,908 & 65,030 \\
\hline Total government debt (in percent of GDP) & 180 & 168 & 162 & 162 & 146 & 144 & 144 & 141 & 136 \\
\hline Of which: foreign denominated debt (in percent of gross debt) & 50 & 50 & 45 & 45 & 39 & 35 & 32 & 29 & 28 \\
\hline
\end{tabular}

Sources: Lebanese authorities; and Fund staff estimates and calculations.

$1 /$ Includes domestic excises, which are collected at customs and are classified as taxes on international trade.

2/ Excludes principal and interest payments paid on behalf of EdL.

3/ From 2005 onward includes additional transfers to the social security funds (NSSF) to clear the stock of arrears.

4/ Includes $\$ 275$ million for telecom settlements (2006 and 2007).

$5 /$ Includes transfers to municipalities.

6/ Debt cancellation and Banque du Liban revaluation of gold in 2007 and projected privatization proceeds in 2010-11. 
Table 4. Lebanon: Government Debt, 2006-14 1/

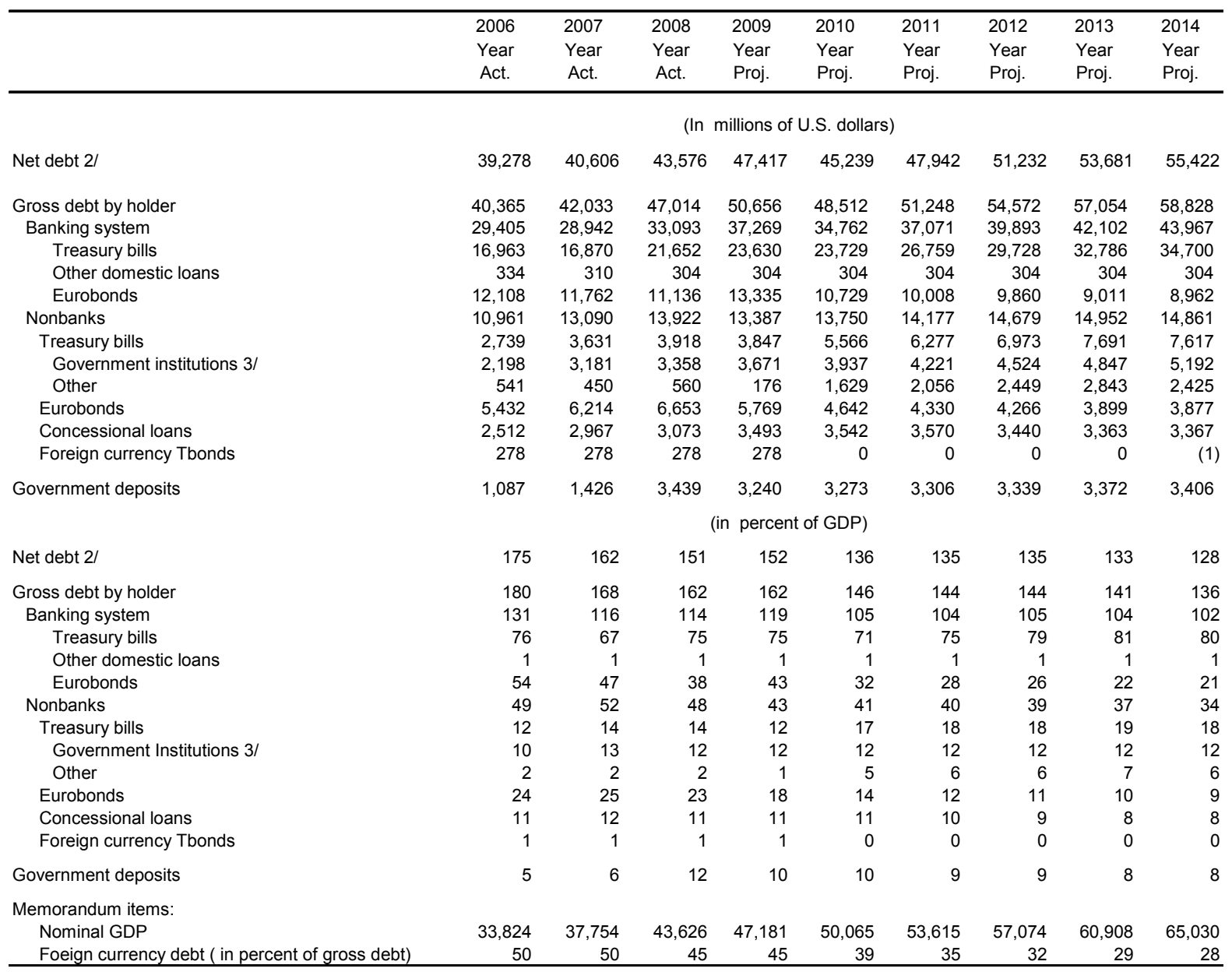

Sources: Lebanese authorities; and Fund staff estimates and calculations.

$1 /$ Includes all debt contracted by the treasury on behalf of the central government and public agencies other than the

Banque du Liban; accrued interest; and Banque du Liban lending to Electricite du Liban. Excludes possible government arrears to the private sector.

2/ Defined as gross debt less government deposits.

3/ Denominated in domestic currency; mainly to the National Social Security Fund, and the National Deposit Insurance Fund. 
Table 5. Lebanon: Monetary Survey, 2006-09

\begin{tabular}{|c|c|c|c|c|}
\hline & $\begin{array}{c}2006 \\
\text { Year } \\
\text { Act. }\end{array}$ & $\begin{array}{c}2007 \\
\text { Year } \\
\text { Act. }\end{array}$ & $\begin{array}{r}2008 \\
\text { Year } \\
\text { Act. }\end{array}$ & $\begin{array}{l}2009 \\
\text { Year } \\
\text { Proj. }\end{array}$ \\
\hline & \multicolumn{4}{|c|}{ (In billions of Lebanese pounds) } \\
\hline Net foreign assets & 43,556 & 50,650 & 59,272 & 60,754 \\
\hline Banque du Liban & 23,047 & 25,538 & 36,927 & 40,860 \\
\hline Commercial banks & 20,510 & 25,112 & 22,344 & 19,894 \\
\hline Net domestic assets & 50,822 & 54,004 & 61,590 & 72,194 \\
\hline Net claims on public sector & 38,981 & 38,661 & 41,397 & 47,721 \\
\hline of which: Net claims on government & 40,871 & 39,955 & 42,751 & 49,347 \\
\hline Banque du Liban & 9,678 & 7,531 & 4,437 & 4,737 \\
\hline Commercial banks & 31,193 & 32,423 & 38,314 & 44,610 \\
\hline Claims on private sector & 23,371 & 27,059 & 32,056 & 35,266 \\
\hline Other items (net) & $-11,530$ & $-11,715$ & $-11,863$ & $-10,794$ \\
\hline Broad money (M5) 1/ & 94,378 & 104,655 & 120,862 & 132,948 \\
\hline In Lebanese pounds & 24,159 & 25,535 & 38,692 & 47,710 \\
\hline Currency in circulation & 1,809 & 1,929 & 2,175 & 2,392 \\
\hline Deposits in Lebanese pounds & 22,350 & 23,606 & 36,517 & 45,318 \\
\hline \multirow[t]{2}{*}{ Deposits in foreign currency } & 70,219 & 79,119 & 82,170 & 85,238 \\
\hline & \multicolumn{4}{|c|}{ (Year-on-year percent change) } \\
\hline Net foreign assets & 15.1 & 3.9 & 17.0 & 2.5 \\
\hline Net domestic assets & -0.1 & 6.3 & 14.0 & 17.2 \\
\hline Net claims on public sector & 5.7 & -0.8 & 7.1 & 15.3 \\
\hline Claims on private sector & -5.7 & 15.8 & 18.5 & 10.0 \\
\hline Broad money (M5) 1/ & 6.4 & 10.9 & 15.5 & 10.0 \\
\hline In Lebanese pounds & -5.3 & 5.7 & 51.5 & 23.3 \\
\hline Deposits in foreign currency & 11.1 & 12.7 & 3.9 & 3.7 \\
\hline \multicolumn{5}{|l|}{ Memorandum items: } \\
\hline & \multicolumn{4}{|c|}{ (In billions of Lebanese pounds, except where otherwise indicated) } \\
\hline \multicolumn{5}{|l|}{ Banque du Liban: } \\
\hline Net foreign exchange position $2 /$ & 3,465 & 4,528 & 12,383 & 16,137 \\
\hline Foreign assets & 26,321 & 29,300 & 40,809 & 44,670 \\
\hline Foreign currency liabilities & 22,856 & 24,773 & 28,426 & 28,533 \\
\hline Net foreign exchange position, in millions of U.S. dollars 2/ & 2,299 & 3,003 & 8,214 & 10,704 \\
\hline Claims on public sector (net) & 9,367 & 7,400 & 4,415 & 4,442 \\
\hline Claims on commercial banks & $-3,796$ & $-2,467$ & $-6,689$ & $-10,094$ \\
\hline Reserve money & 7,227 & 7,919 & 9,430 & 11,368 \\
\hline Gross international reserves (excluding gold), in millions of U.S. dollars $3 /$ & 11,353 & 11,496 & 18,769 & 20,865 \\
\hline in percent of banking system foreign currency deposits & 30.1 & 26.5 & 42.8 & 46.5 \\
\hline in percent of total banking system deposits & 21.9 & 19.7 & 28.2 & 28.4 \\
\hline Share of foreign currency deposits in total private sector deposits (in percent) & 76.2 & 77.4 & 69.6 & 65.6 \\
\hline
\end{tabular}

Sources: Banque du Liban; and Fund staff estimates and projections.

1/ Broad money (M5) is defined as M3 (currency + resident deposits) + non-resident deposits.

2/ Defined by currency (not by residency), as official foreign currency assets, including gold and SDR, less foreign currency liabilities.

Liabilities include the exceptional deposits by GCC governments, but exclude liabilities to the government of Lebanon and other official creditors.

3/ Defined as all official foreign currency assets, less encumbered foreign assets. 
Table 6. Lebanon: Balance of Payments, 2006-14

\begin{tabular}{|c|c|c|c|c|c|c|c|c|c|}
\hline & $\begin{array}{r}2006 \\
\text { Est. }\end{array}$ & $\begin{array}{c}2007 \\
\text { Est. }\end{array}$ & $\begin{array}{c}2008 \\
\text { Prel. }\end{array}$ & $\begin{array}{l}2009 \\
\text { Proj. }\end{array}$ & $\begin{array}{c}2010 \\
\text { Proj. }\end{array}$ & $\begin{array}{c}2011 \\
\text { Proj. }\end{array}$ & $\begin{array}{c}2012 \\
\text { Proj. }\end{array}$ & $\begin{array}{l}2013 \\
\text { Proj. }\end{array}$ & $\begin{array}{c}2014 \\
\text { Proj. }\end{array}$ \\
\hline & \multicolumn{9}{|c|}{ (In millions of U.S. dollars, unless otherwise indicated) } \\
\hline Current account (excl. official transfers) & $-1,538$ & $-1,979$ & $-3,421$ & $-3,360$ & $-3,422$ & $-3,583$ & $-3,647$ & $-3,621$ & $-3,438$ \\
\hline Goods (net) & $-6,138$ & $-7,850$ & $-11,166$ & $-10,077$ & $-10,581$ & $-11,046$ & $-11,543$ & $-12,271$ & $-12,992$ \\
\hline Exports, f.o.b. & 3,207 & 4,077 & 5,149 & 5,406 & 5,893 & 6,482 & 7,195 & 8,023 & 8,985 \\
\hline Imports, f.o.b. & $-9,345$ & $-11,926$ & $-16,315$ & $-15,483$ & $-16,474$ & $-17,529$ & $-18,738$ & $-20,293$ & $-21,978$ \\
\hline Services (net) & 3,022 & 3,197 & 5,805 & 5,670 & 6,316 & 7,004 & 7,706 & 8,383 & 9,109 \\
\hline Income (net) & $-1,200$ & -782 & $-1,565$ & $-1,598$ & $-2,059$ & $-2,699$ & $-3,264$ & $-3,399$ & $-3,484$ \\
\hline Of which: interest on government debt & -457 & -536 & -599 & -492 & -575 & -582 & -572 & -510 & -411 \\
\hline Current transfers (net) $1 /$ & 2,778 & 3,455 & 3,505 & 2,644 & 2,902 & 3,158 & 3,454 & 3,665 & 3,929 \\
\hline Capital and financial account & 1,926 & 495 & 6,997 & 4,621 & 6,580 & 4,422 & 5,280 & 5,652 & 6,349 \\
\hline Capital transfers (net) & 1,340 & 590 & 124 & 64 & 37 & 59 & 67 & 79 & 7 \\
\hline Direct investment (net) $2 /$ & 2,669 & 1,996 & 2,050 & 1,728 & 4,586 & 2,612 & 2,303 & 2,575 & 2,873 \\
\hline Portfolio investment, loans, other capital & $-2,084$ & $-2,091$ & 4,823 & 2,830 & 1,958 & 1,752 & 2,910 & 2,999 & 3,39 \\
\hline Government (net) 3/ & 666 & -225 & -369 & $-1,348$ & -299 & -294 & -158 & -312 & -518 \\
\hline BdL 4/ & 1,507 & 246 & 40 & -48 & -69 & -189 & -111 & -92 & -72 \\
\hline Of which: IMF repurchases & 0 & 0 & 0 & 0 & -19 & -39 & -39 & -20 & \\
\hline Banks (net) $5 /$ & $-1,421$ & $-2,394$ & 4,820 & 3,591 & -393 & 324 & -94 & -501 & -367 \\
\hline Foreign assets of banks $6 /$ & $-2,491$ & $-3,053$ & 1,836 & 1,625 & $-1,658$ & -929 & $-1,459$ & $-1,990$ & $-1,990$ \\
\hline Non-resident deposits 5/ & 1,071 & 659 & 2,985 & 1,966 & 1,266 & 1,253 & 1,366 & 1,489 & 1,623 \\
\hline Non-bank private sector (net) & $-2,836$ & 282 & 332 & 634 & 2,719 & 1,910 & 3,273 & 3,904 & 4,355 \\
\hline Errors and omissions & 1,080 & 955 & 3,119 & 0 & 0 & 0 & 0 & 0 & 0 \\
\hline Overall balance & 1,467 & -529 & 6,695 & 1,261 & 3,158 & 839 & 1,632 & 2,032 & 2,910 \\
\hline Financing & $-1,467$ & 529 & $-6,695$ & $-1,261$ & $-3,158$ & -839 & $-1,632$ & $-2,032$ & $-2,91$ \\
\hline Official reserves (- increase) & $-1,742$ & -143 & $-7,273$ & $-2,096$ & $-3,446$ & $-1,079$ & $-1,757$ & $-2,174$ & $-3,053$ \\
\hline Exceptional financing & 275 & 672 & 578 & 835 & 288 & 240 & 125 & 143 & 143 \\
\hline Budgetary grants & 275 & 195 & 133 & 70 & 94 & 21 & 23 & 26 & 26 \\
\hline Budgetary loans $7 /$ & 0 & 400 & 406 & 765 & 194 & 218 & 102 & 117 & 117 \\
\hline IMF purchases & 0 & 77 & 40 & 0 & 0 & 0 & 0 & 0 & c \\
\hline \multicolumn{10}{|l|}{ Memorandum items: } \\
\hline Current account (incl. official transfers) & $-1,264$ & $-1,784$ & $-3,288$ & $-3,290$ & $-3,328$ & $-3,562$ & $-3,624$ & $-3,595$ & $-3,413$ \\
\hline \multicolumn{10}{|l|}{ Current account balance (in percent of GDP) } \\
\hline Including official transfers & -5.6 & -7.1 & -11.4 & -10.5 & -10.0 & -10.0 & -9.6 & -8.9 & -7 . \\
\hline Excluding official transfers & -6.9 & -7.9 & -11.8 & -10.7 & -10.3 & -10.1 & -9.6 & -9.0 & -8.0 \\
\hline Gross official reserves (excl. gold, year-end) 8/ & 11,353 & 11,496 & 18,769 & 20,865 & 24,312 & 25,390 & 27,148 & 29,322 & 32,375 \\
\hline External debt (year-end; in percent of GDP) 9/ & 198.9 & 194.1 & 190.8 & 182.1 & 181.4 & 185.9 & 194.2 & 194.1 & 194.2 \\
\hline Government external debt (in percent of GDP) & 35.9 & 35.3 & 30.2 & 26.0 & 24.2 & 22.4 & 20.9 & 19.1 & 17. \\
\hline GDP & 22,437 & 25,044 & 28,939 & 31,298 & 33,210 & 35,566 & 37,860 & 40,403 & 43,138 \\
\hline
\end{tabular}

Sources: Lebanese authorities; BIS; and IMF staff estimates and projections.

$1 /$ Excluding official budgetary transfers.

2/ Projections for 2010 include sizeable inflows related to privatization in the telecommunications sector.

3/ Excluding budgetary loan disbursements.

4 / Change in the foreign liabilities of the BdL, excluding IMF purchases.

5/ Differs from banks' reported data, to include estimated deposit flows by Lebanese nationals living abroad but classified as residents.

6/ Net of non-deposit foreign liabilities.

7/ Including disbursements of non-war/non-Paris III related project loans.

8/ Excludes Eurobonds and encumbered reserves.

$9 /$ Includes all banking deposits held by non-residents, including estimated deposits of Lebanese nationals living abroad but classified as residents. 
Table 7. Lebanon: Banking Sector Financial Soundness Indicators, 2006-08

\begin{tabular}{|c|c|c|c|}
\hline & 2006 & 2007 & 2008 \\
\hline & \multicolumn{3}{|c|}{ (In percent, unless otherwise indicated) } \\
\hline Assets (in millions of U.S. dollars) & 78,855 & 88,853 & 101,862 \\
\hline \multicolumn{4}{|l|}{ Capital } \\
\hline Capital adequacy ratio $1 / 2$ / & 25.0 & 12.5 & 11.8 \\
\hline Capital to asset ratio & 9.1 & 8.9 & 7.8 \\
\hline \multicolumn{4}{|l|}{ Asset quality } \\
\hline Net problem loans/net total loans & 6.8 & 4.7 & 3.1 \\
\hline Provisions against problem loans/problem loans & 54.4 & 56.9 & 61.0 \\
\hline Total provisions/problem loans & 72.4 & 76.8 & 85.6 \\
\hline \multicolumn{4}{|l|}{ Asset concentration } \\
\hline Share of claims on government & 27.9 & 26.1 & 27.0 \\
\hline Of which: T-bills & 13.4 & 12.6 & 15.9 \\
\hline Of which: Eurobonds & 14.4 & 13.5 & 11.0 \\
\hline Share of claims on BdL & 27.0 & 24.7 & 27.8 \\
\hline Of which: Certificates of Deposit & 11.7 & 9.0 & 12.1 \\
\hline Share of claims on private sector & 20.6 & 21.6 & 22.3 \\
\hline Share of claims on nonresidents & 18.8 & 20.9 & 16.3 \\
\hline Of which: foreign banks & 16.5 & 17.7 & 12.1 \\
\hline Net foreign currency assets as percent of capital & 15.5 & 18.4 & 20.7 \\
\hline \multicolumn{4}{|l|}{ Earnings } \\
\hline Average return on assets (post tax) & 0.9 & 1.0 & 1.1 \\
\hline Average return on equity (post tax) & 10.1 & 12.1 & 14.0 \\
\hline Net interest margin & 2.0 & 2.0 & 2.0 \\
\hline \multicolumn{4}{|l|}{ Liquidity } \\
\hline Net liquid assets/total assets & 42.9 & 40.3 & 42.2 \\
\hline Net liquid assets/short-term liabilities & 51.0 & 47.9 & 50.1 \\
\hline Private sector deposits/assets & 69.1 & 70.1 & 70.3 \\
\hline Nonresident deposits/assets & 12.6 & 11.7 & 12.2 \\
\hline \multicolumn{4}{|l|}{ Other indicators $3 /$} \\
\hline Change in assets (12 month, in percent) & 7.2 & 12.7 & 14.6 \\
\hline Change in private sector credit ( 12 month, in percent) & 7.3 & 23.6 & 22.1 \\
\hline Change in deposits (12 month, in percent) & 6.5 & 10.8 & 15.6 \\
\hline FC deposits/total deposits & 75.9 & 77.0 & 69.2 \\
\hline FC loans/total loans & 87.1 & 87.5 & 87.6 \\
\hline FC loans/GDP & 64.0 & 73.6 & 75.7 \\
\hline \multicolumn{4}{|l|}{ Memorandum items: } \\
\hline LL deposit rate (average) & 7.5 & 7.5 & 7.3 \\
\hline LL loan rate (average) & 10.3 & 10.3 & 10.0 \\
\hline FC deposit rate (average) & 4.4 & 4.9 & 3.7 \\
\hline FC loan rate (average) & 8.5 & 8.3 & 7.5 \\
\hline Government's 3-year T-bill rate (marginal) & 9.5 & 9.5 & 9.4 \\
\hline Government's Eurobond rate (marginal) & 7.5 & 8.9 & 9.0 \\
\hline Spread over 5-year U.S. note & 2.8 & 4.5 & 6.2 \\
\hline GDP (in millions of U.S. dollars) & 22,437 & 25,044 & 28,939 \\
\hline
\end{tabular}

Sources: Banque du Liban, Banking Control Commission and staff estimates.

1/ From 2007: based on Basel II risk weights.

2/ 2008 value: as of June 2008 (latest available).

3 / FC and LL stand for "foreign currency" and "Lebanese pound," respectively. 
Table 8. Lebanon: Public Sector Debt Sustainability Framework, 2006-14

(In percent of GDP, unless otherwise indicated)

\begin{tabular}{|c|c|c|c|c|c|c|c|c|c|c|}
\hline & \multicolumn{3}{|c|}{ Actual } & \multicolumn{6}{|c|}{ Projections } & \multirow{4}{*}{$\begin{array}{c}\text { Debt-Stabilizing } \\
\text { Primary } \\
\text { Balance } 7 / \\
-0.1\end{array}$} \\
\hline & 2006 & 2007 & 2008 & 2009 & 2010 & 2011 & 2012 & 2013 & 2014 & \\
\hline & & & & & & & & & & \\
\hline Baseline: Public sector debt $1 /$ & 179.9 & 167.8 & 162.5 & 161.9 & 146.1 & 144.1 & 144.1 & 141.2 & 136.4 & \\
\hline Of which: foreign-currency denominated & 89.4 & 83.6 & 72.1 & 72.2 & 56.9 & 50.4 & 46.4 & 40.3 & 37.6 & \\
\hline Change in public sector debt & 4.2 & -12.1 & -5.4 & -0.6 & -15.8 & -2.0 & 0.0 & -2.9 & -4.8 & \\
\hline Identified debt-creating flows & 6.9 & -14.3 & -12.6 & 0.0 & -15.9 & -2.1 & 0.0 & -3.0 & -5.9 & \\
\hline Primary deficit & -1.7 & -1.8 & -1.4 & -0.5 & -3.3 & -2.8 & -4.1 & -5.7 & -5.8 & \\
\hline Revenue and grants & 25.1 & 24.4 & 24.8 & 25.2 & 24.4 & 23.4 & 23.8 & 25.3 & 25.3 & \\
\hline Primary (noninterest) expenditure & 23.4 & 22.7 & 23.3 & 24.8 & 21.1 & 20.6 & 19.7 & 19.7 & 19.5 & \\
\hline Automatic debt dynamics $2 /$ & 8.6 & -6.2 & -11.2 & 0.5 & 3.8 & 3.8 & 4.0 & 2.6 & -0.1 & \\
\hline Contribution from interest rate/growth differential 3/ & 8.6 & -6.2 & -11.2 & 0.5 & 3.8 & 3.8 & 4.0 & 2.6 & -0.1 & \\
\hline Of which: contribution from real interest rate & 9.7 & 5.9 & 1.2 & 5.0 & 9.9 & 9.3 & 10.1 & 8.7 & 5.2 & \\
\hline Of which: contribution from real GDP growth & -1.0 & -12.1 & -12.3 & -4.5 & -6.1 & -5.5 & -6.1 & -6.1 & -5.3 & \\
\hline Contribution from exchange rate depreciation $4 /$ & 0.0 & 0.0 & 0.0 & $\ldots$ & $\ldots$ & $\ldots$ & $\ldots$ & $\ldots$ & $\ldots$ & \\
\hline Other identified debt-creating flows & 0.0 & -6.3 & 0.0 & 0.0 & -16.3 & -3.1 & 0.0 & 0.0 & 0.0 & \\
\hline Privatization receipts (negative) & 0.0 & 0.0 & 0.0 & 0.0 & -16.3 & -3.1 & 0.0 & 0.0 & 0.0 & \\
\hline Recognition of implicit or contingent liabilities & 0.0 & 0.0 & 0.0 & 0.0 & 0.0 & 0.0 & 0.0 & 0.0 & 0.0 & \\
\hline Other (Paris II and III assistance) & 0.0 & -6.3 & 0.0 & 0.0 & 0.0 & 0.0 & 0.0 & 0.0 & 0.0 & \\
\hline Residual, including asset changes $5 /$ & -2.8 & 2.2 & 7.2 & -0.6 & 0.1 & 0.1 & 0.1 & 0.1 & 1.0 & \\
\hline Public sector debt-to-revenue ratio $1 /$ & 717.1 & 687.2 & 656.3 & 641.0 & 598.6 & 617.0 & 605.4 & 557.3 & 539.3 & \\
\hline \multicolumn{11}{|l|}{ Key Macroeconomic and Fiscal Assumptions Underlying Baseline } \\
\hline Real GDP growth (in percent) & 0.6 & 7.5 & 8.5 & 3.0 & 4.0 & 4.0 & 4.5 & 4.5 & 4.0 & \\
\hline Average nominal interest rate on public debt (in percent) $6 /$ & 7.6 & 7.8 & 7.9 & 8.5 & 8.6 & 9.9 & 9.4 & 8.7 & 6.2 & \\
\hline Average real interest rate (nominal rate minus change in GDP deflator, in percent) & 5.7 & 3.9 & 1.4 & 3.5 & 6.6 & 6.9 & 7.6 & 6.6 & 4.0 & \\
\hline Nominal appreciation (increase in U.S. dollar value of local currency, in percent) & 0.0 & 0.0 & 0.0 & $\ldots$ & $\ldots$ & $\ldots$ & $\ldots$ & $\ldots$ & $\ldots$ & \\
\hline Inflation rate (GDP deflator, in percent) & 1.9 & 3.8 & 6.5 & 5.0 & 2.0 & 3.0 & 1.9 & 2.1 & 2.2 & \\
\hline Growth of real primary spending (deflated by GDP deflator, in percent) & 15.4 & 4.2 & 11.7 & 9.5 & -11.7 & 1.5 & 0.3 & 4.2 & 3.7 & \\
\hline Primary deficit & -1.7 & -1.8 & -1.4 & -0.5 & -3.3 & -2.8 & -4.1 & -5.7 & -5.8 & \\
\hline \multicolumn{11}{|l|}{ Memorandum items: } \\
\hline Public sector debt based on historical GDP growth data $8 /$ & 178.7 & 178.1 & 172.8 & 172.4 & 153.5 & 145.8 & 141.3 & 136.6 & 133.9 & \\
\hline Public sector debt based on historical data $9 /$ & 178.7 & 178.1 & 172.8 & 177.1 & 163.4 & 160.9 & 161.8 & 162.5 & 165.2 & \\
\hline
\end{tabular}

Sources: Lebanese authorities; and Fund staff projections.

$1 /$ Central government gross debt.

$2 /$ Derived as $[(r-p(1+g)-g+a e(1+r)] /(1+g+p+g p))$ times previous period debt ratio, with $r=$ interest rate; $p=$ growth rate of GDP deflator; $g=$ real GDP growth rate; $a=$ share of foreign-currency denominated debt; and $\mathrm{e}=$ nominal exchange rate depreciation (measured by increase in local currency value of U.S. dollar).

$3 /$ The real interest rate contribution is derived from the denominator in footnote $2 /$ as $r-\pi(1+g)$ and the real growth contribution as $-g$

$4 /$ The exchange rate contribution is derived from the numerator in footnote $2 /$ as ae $(1+r)$

$5 /$ For projections, this line includes exchange rate changes.

6/ Derived as nominal interest expenditure divided by previous period debt stock.

7/ Assumes that key variables (real GDP growth, real interest rate, and other identified debt-creating flows) remain at the level of the last projection year

8/ This path assumes that, from 2009 onwards, real GDP growth is set at its 10-year average level while the primary fiscal balance and real interest rates are the same as in the baseline scenario.

9/ This path assumes that, from 2009 onwards, real interest rate and real GDP growth are set at their 10-year average level while the primary fiscal balance is the same as in the baseline scenario. 
Table 9. Lebanon: Indicators of Financial and External Vulnerability, 2006-09

\begin{tabular}{|c|c|c|c|c|}
\hline & $\begin{array}{r}2006 \\
\text { Act. }\end{array}$ & $\begin{array}{r}2007 \\
\text { Act. }\end{array}$ & $\begin{array}{r}2008 \\
\text { Est. }\end{array}$ & $\begin{array}{r}2009 \\
\text { Proj. }\end{array}$ \\
\hline \multicolumn{5}{|c|}{ (In millions of U.S. dollars, unless otherwise indicated) } \\
\hline \multicolumn{5}{|l|}{ Monetary and financial indicators } \\
\hline Broad money, M5 & 62,606 & 69,423 & 80,174 & 88,191 \\
\hline Annual percentage change & 6.4 & 10.9 & 15.5 & 10.0 \\
\hline Private sector credit (annual percentage change) & -5.7 & 15.8 & 18.5 & 10.0 \\
\hline \multicolumn{5}{|l|}{ Public finance indicators } \\
\hline Overall fiscal balance & $-2,523$ & $-2,700$ & $-2,892$ & $-3,841$ \\
\hline In percent of GDP & -11.2 & -10.8 & -10.0 & -12.3 \\
\hline In percent of government revenue & -44.8 & -44.1 & -40.4 & -48.6 \\
\hline Interest payments on debt & 2,906 & 3,139 & 3,303 & 3,982 \\
\hline In percent of GDP & 13.0 & 12.5 & 11.4 & 12.7 \\
\hline In percent of government revenue & 51.6 & 51.3 & 46.1 & 50.4 \\
\hline Nominal GDP & 22,437 & 25,044 & 28,939 & 31,298 \\
\hline Government revenue & 5,631 & 6,119 & 7,166 & 7,905 \\
\hline \multicolumn{5}{|l|}{ Banking-sector indicators } \\
\hline Problem loans (in percent of total loans, net of provisions and unearned interest) & 6.8 & 4.7 & 3.1 & $\ldots$ \\
\hline Provisions against problem loans (in percent of problem loans) & 72.4 & 76.8 & 85.6 & $\ldots$ \\
\hline Capital adequacy ratio & 25.0 & 12.5 & 11.8 & \\
\hline Credit to the private sector (in percent of GDP) & 69.1 & 71.7 & 73.5 & 74.7 \\
\hline \multicolumn{5}{|l|}{ Debt indicators } \\
\hline Gross public debt & 40,365 & 42,033 & 47,014 & 50,656 \\
\hline In percent of government revenue & 716.8 & 687.0 & 656.1 & 640.8 \\
\hline In percent of GDP & 179.9 & 167.8 & 162.5 & 161.9 \\
\hline Of which: foreign currency & 20,330 & 21,221 & 21,140 & 22,876 \\
\hline In percent of GDP & 90.6 & 84.7 & 73.0 & 73.1 \\
\hline Gross public debt held by the market & 27,871 & 29,206 & 33,993 & $\ldots$ \\
\hline In percent of GDP & 124.2 & 116.6 & 117.5 & \\
\hline External debt $1 /$ & 44,617 & 48,600 & 55,216 & 56,995 \\
\hline In percent of GDP & 198.9 & 194.1 & 190.8 & 182.1 \\
\hline External public debt (central government and Banque du Liban) & 10,222 & 11,347 & 11,306 & 10,676 \\
\hline In percent of GDP & 45.6 & 45.3 & 39.1 & 34.1 \\
\hline Short-term external public debt $2 /$ & 1,455 & 1,421 & 2,445 & 1,624 \\
\hline Short-term foreign currency public debt $2 /$ & 2,039 & 2,777 & 3,111 & 5,281 \\
\hline Short-term external debt $1 / 2 /$ & 35,850 & 38,674 & 46,355 & 47,943 \\
\hline Short-term foreign currency debt $2 / 3 /$ & 54,268 & 62,984 & 69,067 & 73,737 \\
\hline Total foreign currency deposits (resident and non-resident) $1 /$ & 46,319 & 52,099 & 54,175 & 56,232 \\
\hline \multicolumn{5}{|l|}{ International reserves } \\
\hline Gross official reserves $4 /$ & 11,353 & 11,496 & 18,769 & 20,866 \\
\hline In percent of short-term external debt & 32 & 30 & 40 & 44 \\
\hline Gross official reserves and commercial banks' foreign assets & 27,768 & 32,205 & 37,896 & 38,367 \\
\hline In percent of short-term external debt & 77 & 83 & 82 & 80 \\
\hline In percent of short-term foreign currency debt $3 /$ & 51 & 51 & 55 & 52 \\
\hline \multicolumn{5}{|l|}{ External current account indicators } \\
\hline Merchandise exports, f.o.b. & 3,207 & 4,077 & 5,149 & 5,406 \\
\hline Annual percentage change & 40.8 & 27.1 & 26.3 & 5.0 \\
\hline Merchandise imports, f.o.b. & 9,345 & 11,926 & 16,315 & 15,483 \\
\hline Annual percentage change & 11.3 & 27.6 & 36.8 & -5.1 \\
\hline External current account balance & $-1,264$ & $-1,784$ & $-3,288$ & $-3,290$ \\
\hline In percent of GDP & -5.6 & -7.1 & -11.4 & -10.5 \\
\hline In percent of exports of goods and services & -9.2 & -11.1 & -14.4 & -13.8 \\
\hline
\end{tabular}

Sources: Lebanese authorities; Bank for International Settlements; and Fund staff estimates and projections.

$1 /$ Includes estimates for public debt and banking deposits held by non-residents, and non-resident claims on the nonfinancial sector. 2/ On a remaining maturity basis (scheduled amortization over the next year).

$3 /$ Short-term foreign currency debt of the public sector and the banking sector plus external debt of the nonbank sector.

4/ Excludes gold and encumbered assets. 
Table 10. Lebanon: External Financing Requirements and Sources, 2006-10

\begin{tabular}{|c|c|c|c|c|c|}
\hline & $\begin{array}{r}2006 \\
\text { Act. }\end{array}$ & $\begin{array}{r}2007 \\
\text { Act. }\end{array}$ & $\begin{array}{l}2008 \\
\text { Prel. } \\
\end{array}$ & $\begin{array}{l}2009 \\
\text { Proj. } \\
\end{array}$ & $\begin{array}{l}2010 \\
\text { Proj. }\end{array}$ \\
\hline \multicolumn{6}{|c|}{ (In millions of U.S. dollars) } \\
\hline Gross financing requirements & $-32,004$ & $-32,063$ & $-41,259$ & $-40,031$ & $-42,587$ \\
\hline External current account balance 1/ & $-1,538$ & $-1,979$ & $-3,421$ & $-3,360$ & $-3,422$ \\
\hline Government debt amortization & $-1,308$ & $-1,455$ & $-1,421$ & $-2,445$ & $-1,624$ \\
\hline Non-resident deposits & $-27,415$ & $-28,486$ & $-29,145$ & $-32,129$ & $-34,095$ \\
\hline Repayment of arrears & 0 & 0 & 0 & 0 & 0 \\
\hline Gross reserves accumulation (- increase) & $-1,742$ & -143 & $-7,273$ & $-2,096$ & $-3,446$ \\
\hline IMF repurchases & 0 & 0 & 0 & 0 & 0 \\
\hline Available financing & 31,729 & 31,391 & 40,681 & 39,195 & 42,319 \\
\hline Capital transfers (net) & 1,340 & 590 & 124 & 64 & 37 \\
\hline Foreign direct investment (net) & 2,669 & 1,996 & 2,050 & 1,728 & 4,586 \\
\hline Portfolio investment, loans, other capital & 26,640 & 27,850 & 35,388 & 37,404 & 37,697 \\
\hline Government (excl. budget loans) & 1,974 & 1,230 & 1,052 & 1,097 & 1,325 \\
\hline Banque du Liban (liabilities, net) 2/ & 1,507 & 246 & 40 & -48 & -50 \\
\hline Commercial Banks & 25,995 & 26,092 & 33,965 & 35,720 & 33,702 \\
\hline Non-resident deposits & 28,486 & 29,145 & 32,129 & 34,095 & 35,361 \\
\hline Other (net) & $-2,491$ & $-3,053$ & 1,836 & 1,625 & $-1,658$ \\
\hline Non-bank private sector (net) & $-2,836$ & 282 & 332 & 634 & 2,719 \\
\hline Errors and omissions & 1,080 & 955 & 3,119 & 0 & 0 \\
\hline Financing gap & -275 & -672 & -578 & -835 & -269 \\
\hline Exceptional financing & 275 & 672 & 578 & 835 & 269 \\
\hline Exceptional grants to government & 275 & 195 & 133 & 70 & 94 \\
\hline Exceptional loans to government & 0 & 400 & 406 & 765 & 194 \\
\hline IMF purchases (net) & 0 & 77 & 40 & 0 & -19 \\
\hline Residual financing gap & 0 & 0 & 0 & 0 & 0 \\
\hline
\end{tabular}

Sources: Lebanese authorities; BIS; and IMF staff estimates and projections.

$1 /$ Excluding official transfers.

2/ Excluding IMF. 
Table 11. Lebanon: Indicators of Capacity to Repay the Fund, 2006-14

\begin{tabular}{|c|c|c|c|c|c|c|c|c|c|}
\hline & $\begin{array}{r}2006 \\
\text { Act. }\end{array}$ & $\begin{array}{r}2007 \\
\text { Act. }\end{array}$ & $\begin{array}{c}2008 \\
\text { Est. }\end{array}$ & $\begin{array}{c}2009 \\
\text { Proj. }\end{array}$ & $\begin{array}{c}2010 \\
\text { Proj. }\end{array}$ & $\begin{array}{c}2011 \\
\text { Proj. }\end{array}$ & $\begin{array}{c}2012 \\
\text { Proj. }\end{array}$ & $\begin{array}{c}2013 \\
\text { Proj. }\end{array}$ & $\begin{array}{c}2014 \\
\text { Proj. }\end{array}$ \\
\hline \multicolumn{10}{|l|}{ Fund repurchases and charges } \\
\hline In millions of SDRs & 0.0 & 1.5 & 2.1 & 1.3 & 13.9 & 26.2 & 25.8 & 12.8 & 0.0 \\
\hline In millions of U.S. dollars & 0.0 & 2.4 & 3.2 & 2.0 & 21.2 & 40.1 & 39.6 & 19.8 & 0.0 \\
\hline In percent of exports and goods and NFS & 0.0 & 0.0 & 0.0 & 0.0 & 0.1 & 0.1 & 0.1 & 0.1 & 0.0 \\
\hline In percent of government external debt service & 0.0 & 0.1 & 0.2 & 0.1 & 1.0 & 1.9 & 1.9 & 1.0 & 0.0 \\
\hline In percent of quota & 0.0 & 0.8 & 1.0 & 0.6 & 6.8 & 12.9 & 12.7 & 6.3 & 0.0 \\
\hline In percent of gross official reserves & 0.0 & 0.0 & 0.0 & 0.0 & 0.1 & 0.2 & 0.1 & 0.1 & 0.0 \\
\hline \multicolumn{10}{|l|}{ Fund credit outstanding } \\
\hline In millions of SDRs & 0.0 & 50.8 & 76.1 & 76.1 & 63.4 & 38.1 & 12.7 & 0.0 & 0.0 \\
\hline In millions of U.S. dollars & 0.0 & 77.7 & 119.8 & 114.7 & 96.7 & 58.2 & 19.5 & 0.0 & 0.0 \\
\hline In percent of quota & 0.0 & 25.0 & 37.5 & 37.5 & 31.3 & 18.7 & 6.3 & 0.0 & 0.0 \\
\hline In percent of GDP & 0.0 & 0.3 & 0.4 & 0.4 & 0.3 & 0.2 & 0.1 & 0.0 & 0.0 \\
\hline In percent of gross official reserves & 0.0 & 0.7 & 0.6 & 0.5 & 0.4 & 0.2 & 0.1 & 0.0 & 0.0 \\
\hline \multicolumn{10}{|l|}{ Memorandum items: } \\
\hline Exports of goods and NFS (in millions of US\$) & 13,711 & 16,005 & 22,838 & 23,929 & 25,847 & 28,091 & 30,449 & 32,998 & 35,809 \\
\hline Government external debt service (in millions of US\$) & 1,765 & 1,991 & 2,020 & 2,937 & 2,199 & 2,069 & 2,134 & 2,037 & 2,352 \\
\hline Quota (in millions of SDRs) & 203 & 203 & 203 & 203 & 203 & 203 & 203 & 203 & 203 \\
\hline Quota (in millions of US\$) & 299 & 311 & 321 & 308 & 309 & 310 & 312 & 313 & 314 \\
\hline Gross official reserves (in millions of US\$) & 11,353 & 11,496 & 18,769 & 20,865 & 24,312 & 25,390 & 27,148 & 29,322 & 32,375 \\
\hline
\end{tabular}

Sources: Lebanese authorities; and IMF staff estimates and calculations. 
Table 12. Lebanon: Monitorable Actions, December 2008-June 2009

Measure Target Date Implementation

Fiscal

Submit to parliament the Global Income Tax draft law

End-March 2009

Establish a Treasury Single Account

End-June 2009

\section{Banque du Liban}

Establish an investment committee and draft formal guidelines for foreign reserve management.

End-December 2008 Done on January 28, 2009.

Adopt formal policies for the selection, appointment, and rotation of the BdL's external auditors.

End-June 2009

Done on January 28 , 2009.

\section{Power sector}

Revise electricity tariff structure consistent with program objectives.

\section{Privatization}

Issue a Request for Application in participating in the process of acquiring the licenses and assets of the two End-March 2009 Privatization has been postponed due to mobile telephone companies (MIC1 and MIC2).

End-December 2008 Not met. unfavorable international capital markets. 
Table 13. Lebanon: Quantitative Indicative Targets Under the Program Supported by Emergency Post-Conflict Assistance, December 2008-June 2009 (In billions of Lebanese pounds unless otherwise indicated; end-of-period) 1/

\begin{tabular}{|c|c|c|c|c|c|c|c|c|}
\hline & & \multicolumn{3}{|c|}{2008} & \multicolumn{4}{|c|}{2009} \\
\hline & & \multirow[b]{2}{*}{ Prog. } & \multirow[b]{2}{*}{ Adj. Prog. } & \multirow[b]{2}{*}{ Est. } & Mar & \multirow{2}{*}{$\begin{array}{r}\text { Jun } \\
\text { Prog. }\end{array}$} & \multirow{2}{*}{$\begin{array}{r}\text { Sep } \\
\text { EPCA Proj. }\end{array}$} & \multirow{2}{*}{$\begin{array}{r}\text { Dec } \\
\text { EPCA Proj. }\end{array}$} \\
\hline & & & & & Prog. & & & \\
\hline I. & Gross reserves of the Banque du Liban (stocks) $2 /$ & 24,718 & 24,509 & 26,793 & 24,867 & 25,436 & 27,818 & 29,049 \\
\hline & Primary balance of the government, before grants (cumulative flows) & 79 & 135 & 292 & -346 & 314 & 157 & 283 \\
\hline III. & Government net borrowing from the Banque du Liban (stocks) & 5,905 & 5,984 & 4,428 & 5,700 & 5,700 & 4,469 & 4,388 \\
\hline IV. & Accumulation of government gross arrears (cumulative flows, continuous) & 0 & 0 & 0 & 0 & 0 & 0 & 0 \\
\hline & $\begin{array}{l}\text { Accumulation of external arrears by the government and the Banque du Liban } \\
\text { (cumulative flows, continuous) }\end{array}$ & 0 & 0 & 0 & 0 & 0 & 0 & 0 \\
\hline \multicolumn{9}{|c|}{ Memorandum items: } \\
\hline & Outstanding letters of credit contracted by Electricité du Liban (stock, millions of U.S. dollars) & 1,046 & & 997 & 766 & 733 & 777 & 777 \\
\hline & Disbursements of official grants and loans to government (cumulative flows) & 1,304 & & 1,022 & 222 & 365 & 822 & 1,431 \\
\hline & Banque du Liban's holdings of Republic of Lebanon Eurobonds (stock) & 1,187 & & 1,155 & 1,187 & 1,187 & 1,187 & 1,187 \\
\hline & Disbursements of grants to the government (cumulative flows) & 522 & & 387 & 39 & 113 & 186 & 237 \\
\hline & Of which: disbursements of project grants (cumulative flows) & 242 & & 187 & 39 & 56 & 73 & 90 \\
\hline & Transfers of gold valuation gains from Banque du Liban to government (cumulative flows) & 0 & & 0 & 0 & 0 & 0 & 0 \\
\hline & Projection of revenue from companies slated for privatization (cumulative flows) & $\ldots$ & & $\ldots$ & 415 & 830 & 909 & 988 \\
\hline
\end{tabular}

Source: Lebanese authorities.

1/ At program (end-December 2007) exchange rates.

2/ In millions of U.S. dollars. Defined as Banque du Liban's foreign exchange deposits abroad, foreign exchange holdings (including SDRs), gold and holdings

of liquid foreign currency-denominated securities, less encumbered foreign assets. 


\section{INTERNATIONAL MONETARY FUND}

\section{LEBANON}

Staff Report for the 2009 Article IV Consultation and Assessment of Performance Under the Program Supported by Emergency Post-Conflict Assistance-Informational Annex

Prepared by Middle East and Central Asia Department

March 31, 2009

Contents

Page

Annexes

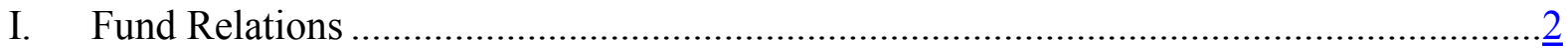

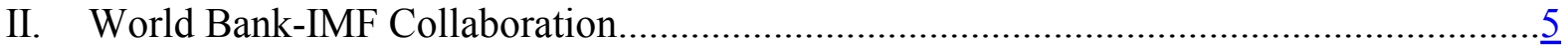

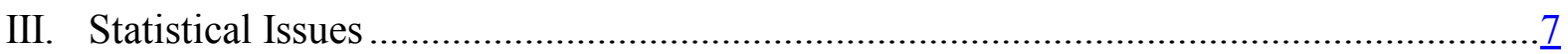




\section{Annex I. Lebanon: Fund Relations}

(As of February 28, 2009)

I. Membership Status: Joined 04/14/47; Article VIII (07/01/93).

II. General Resources Account:

Quota

Fund holdings of currency

Reserve position in Fund

III. SDR Department:

Net cumulative allocation

Holdings

IV. Outstanding Purchases and Loans:

Post-Conflict Emergency Assistance

V. Latest Financial Arrangements:

VI. Projected Obligations to Fund:

(SDR Million; based on existing use of resources and present holdings of SDRs):

\begin{tabular}{lrrrrr}
\hline & \multicolumn{5}{c}{ Forthcoming } \\
\cline { 2 - 6 } & 2009 & 2010 & 2011 & 2012 & 2013 \\
\hline Principal & & 12.69 & 25.38 & 25.38 & 12.69 \\
Charges/Interest & 0.91 & 1.17 & 0.83 & 0.40 & 0.13 \\
\hline Total & $\mathbf{0 . 9 1}$ & $\mathbf{1 3 . 8 6}$ & $\mathbf{2 6 . 2 1}$ & $\mathbf{2 5 . 7 7}$ & $\mathbf{1 2 . 8 2}$
\end{tabular}

VII. Implementation of HIPC Initiative: Not Applicable

VIII. Implementation of Multilateral Debt Relief Initiative (MDRI): Not Applicable

IX. Safeguards Assessment:

Pursuant to Fund policy, the Banque du Liban (BdL) was subject to a full safeguards assessment in conjunction with the first Emergency Post-Conflict Assistance (EPCA). The safeguards assessment report, which was completed on March 10, 2008, recommended several specific measures for enhancing the BdL's financial reporting, audit, and control procedures, and the authorities have outlined steps to follow up on these recommendations. The report also suggested an update of the central bank law. An update safeguards assessment is currently under way in the context of the second EPCA. 


\section{Nonfinancial Relations}

\section{Exchange Arrangement}

The Lebanese pound is a conventional peg. Since October 1999, the BdL has intervened to keep the pound around a mid-point parity of LL 1,507.5 per \$1, with a bid-ask spread of LL+/-6.5.

\section{Article IV Consultation}

The 2007 Article IV consultation was concluded by the Executive Board on October 3, 2007 (IMF Country Report No. 07/382).

\section{Financial Sector Assessment Program}

Lebanon participated in the Financial Sector Assessment Program in 1999, and the related report was presented to the Executive Board at the time of the Article IV consultation. A Financial System Stability Assessment update was conducted in 2001, and the related report similarly presented to the Executive Board at the time of the Article IV consultation.

\section{Technical Assistance}

Fiscal area-FAD has provided advice on introducing the VAT, reforming customs tariffs and income taxes, strengthening tax and customs administration, improving public expenditure management, and consolidating fiscal accounts. A fiscal ROSC report was published in May 2005. Considerable needs remain in tax policy, tax administration, budget preparation, fiscal management, and public accounting and reporting. Technical assistance missions in 2005 primarily dealt with (i) the consolidation of fiscal accounts, and (ii) public liquidity management. In October 2006, a multi-sector mission provided advice on fiscal reform priorities after the conflict with Israel. In November 2007, a FAD mission provided advice for reforming subsidies and restoring gasoline excises. During 2007 and early 2008, FAD and the Middle East Technical Assistance Center (METAC) also provided targeted follow-up support to ongoing initiatives in both tax administration and public financial management (e.g., tax audit program. Treasury Single Account, and cash management).

Financial area-Over the past few years, the now Monetary and Capital Markets Department has provided technical assistance in the areas of the payments system and vulnerability indicators. The related missions undertook an assessment of compliance with Core Principles for Systemically Important Payments Systems, advised on developing systems to improve efficiency and liquidity management in public sector payments and receipts, and assisted in the elaboration of a framework for collecting and analyzing macro-prudential indicators to develop capacity to monitor systemic financial sector vulnerabilities. Progress in implementing IMF recommendations has been limited. In 2006, a mission conducted an assessment of banking sector soundness, including a stress-test exercise, with a view to developing a strategy for banking sector consolidation. 
Statistical area-The Statistics Department has provided technical assistance in national accounts, price and balance of payments statistics. There is no official producer price index (PPI); and balance of payments data remain incomplete. During 2007, several missions on the consumer price index (CPI) were undertaken through the METAC. As a result, in March 2008 a new monthly country-wide CPI was launched. A METAC-STA mission in October-November 2008 has provided assistance on national accounts statistics and economic surveys. In March 2008, a METAC mission provided technical assistance on balance of payments and international investment position statistics. Nevertheless, statistical gaps remain substantial, particularly in the areas of national accounts, price statistics, and the balance of payments. Stronger political commitment to filling these gaps is needed in order for further technical assistance to be effective. 


\section{Annex II. Lebanon: World Bank-IMF Collaboration}

Joint-Management Action Plan Implementation Table, FY 2010

As of March 13, 2009

\begin{tabular}{|c|c|c|c|}
\hline Title & Products & $\begin{array}{c}\text { Provisional Timing of } \\
\text { Missions }\end{array}$ & $\begin{array}{c}\text { Expected } \\
\text { Delivery Date }\end{array}$ \\
\hline \multicolumn{4}{|c|}{ A. Mutual Information on Relevant Work Programs } \\
\hline $\begin{array}{l}\text { Bank work } \\
\text { program in } \\
\text { next } 12 \\
\text { months }\end{array}$ & $\begin{array}{l}\text { Country Assistance } \\
\text { Strategy } \\
\text { Social Impact Analysis for } \\
\text { Electricity and Water } \\
\text { Sectors } \\
\text { Survey-Based Investment } \\
\text { Climate Assessment (ICA) } \\
\text { Update } \\
\text { Emergency Fiscal } \\
\text { Management Reform } \\
\text { Implementation Support } \\
\text { (budget, debt and aid } \\
\text { management reforms) } \\
\text { Statistics TA (social } \\
\text { statistics, statistical } \\
\text { master plan) } \\
\text { Sector work on social } \\
\text { safety net, gender, health, } \\
\text { energy, water and } \\
\text { environment }\end{array}$ & $\begin{array}{l}\text { Ongoing technical } \\
\text { assistance on poverty } \\
\text { analysis and social } \\
\text { statistics. } \\
\\
\text { Work will be ongoing } \\
\text { throughout FY10. Over } \\
\text { the coming period, areas } \\
\text { of focus are: pensions; } \\
\text { labor market reform; } \\
\text { technical assistance for } \\
\text { LNG and energy } \\
\text { efficiency; and continued } \\
\text { engagement in education, } \\
\text { health, water and } \\
\text { environment sectors. }\end{array}$ & $\begin{array}{l}\text { Board Discussion: } \\
03 / 23 / 2010 \\
\text { Final report to } \\
\text { Government by April } \\
2009 . \\
\\
\text { Draft report to } \\
\text { Government in the } \\
\text { second half of } 2009 \text {. } \\
\text { Implementation } \\
\text { through September } \\
2011 .\end{array}$ \\
\hline
\end{tabular}




\begin{tabular}{|c|c|c|c|}
\hline Title & Products & $\begin{array}{c}\text { Provisional Timing of } \\
\text { Missions }\end{array}$ & $\begin{array}{c}\text { Expected } \\
\text { Delivery Date }\end{array}$ \\
\hline \multirow{6}{*}{$\begin{array}{l}\text { IMF work } \\
\text { program }\end{array}$} & Article IV consultations & February-March 2009 & April 2009 \\
\hline & $\begin{array}{l}\text { Review of performance } \\
\text { under EPCA }\end{array}$ & February-March 2009 & April 2009 \\
\hline & $\begin{array}{l}\text { Staff visit for review of } \\
\text { performance under EPCA }\end{array}$ & May 2009 & June 2009 \\
\hline & $\begin{array}{l}\text { Staff visit for review of } \\
\text { performance under EPCA }\end{array}$ & September 2009 & October 2009 \\
\hline & Article IV consultations & February 2009 & April 2009 \\
\hline & $\begin{array}{l}\text { Technical assistance } \\
\text { missions on: } \\
\text { - Public financial } \\
\text { management } \\
\text { - Revenue administration } \\
\text { - Central bank accounting } \\
\text { - Cross border bank } \\
\text { supervision }\end{array}$ & & \\
\hline \multicolumn{4}{|c|}{ B. Requests for Work Program Inputs } \\
\hline $\begin{array}{l}\text { Fund } \\
\text { requests } \\
\text { to Bank }\end{array}$ & $\begin{array}{l}\text { - Update on energy sector } \\
\text { reform } \\
\text { - Update on social safety } \\
\text { net }\end{array}$ & As needed & \\
\hline $\begin{array}{l}\text { Bank } \\
\text { requests } \\
\text { to Fund }\end{array}$ & $\begin{array}{l}\text { Assessment of } \\
\text { macroeconomic policies } \\
\text { and prospects }\end{array}$ & $\begin{array}{l}\text { Semiannual (and on ad } \\
\text { hoc basis if requested) }\end{array}$ & $\begin{array}{l}\text { Following Article IV } \\
\text { and staff visits }\end{array}$ \\
\hline \multicolumn{4}{|c|}{ C. Agreement on Joint Products and Missions } \\
\hline $\begin{array}{l}\text { Joint } \\
\text { products }\end{array}$ & FSAP Update (tentative) & October 2009 & $\begin{array}{l}\text { December-January } \\
2009\end{array}$ \\
\hline
\end{tabular}




\title{
ANNEX III. LEBANON-STATISTICAL ISSUES
}

\author{
As of March 12, 2009
}

\section{Assessment of Data Adequacy for Surveillance}

General: Data provision has serious shortcomings that significantly hamper surveillance. In particular, there are serious issues in the compilation of the national accounts, employment, general government and the rest of the nonfinancial public sector, and balance of payments.

National Accounts: The national accounts data are weak. Despite technical assistance from the French National Institute of Statistics and Economic Studies, the Central Administration of Statistics (CAS) still does not have the capacity to produce national accounts statistics in line with accepted international standards. National accounts (now up to 2007) are instead produced in the Prime Minister's office. STA is assisting the authorities to produce national accounts estimates based on a comprehensive data collection program and the 2004 economic survey.

Price statistics: Since May 2008, CAS compiles and disseminates a monthly Consumer Price Index (CPI) following international accepted methodology. The CPI is disseminated within three weeks after the end of the reference month. Geographical coverage is expanded to include all areas in Lebanon (a previous CAS index was based on prices collected from Beirut and its suburbs).

Government finance statistics: Fiscal statistics are weak. Published monthly data on the central government budgetary accounts are not comprehensive, omit certain transfers, financing data, and foreign-financed capital expenditure, and do not cover arrears. Certain (treasury) spending is only identified ex-post, and its economic classification with a lag. However, these items are provided to the staff in the context of surveillance activities. Government finance statistics are on a cash basis, with a modified cash cash-basis for budgetary expenditure data, corresponding to the issue of payment orders. In addition, there are no data on the widespread quasi-fiscal activities conducted by public corporations.

Monetary and financial statistics: Monetary statistics are adequate. At the same time, sectoralization of institutional units and classification of financial instruments in the data reported to STA fall significantly short of what is needed for compilation of Standardized Report Forms (SRFs). The lack of a reliable classification of deposits by residency complicates the balance of payments analysis. The reporting of monetary data to STA is irregular and occurs with a three- to four-month lag.

Balance of payments: The balance of payments statistics are weak. The data reflect deficiencies in the current account (unrecorded exports, underestimation of private sector services and workers' remittances), the capital account (grants), and the financial account (equity investment in the nonbank private sector, and corporate borrowing abroad). Coverage of foreign direct investment transactions remains limited. Lack of effective interagency cooperation, and staff constraints at both Banque du Liban (BDL) and CAS are among the main factors impeding progress.

\section{Data Standards and Quality}

Participant in the General Data Dissemination System since January 2003. Metadata and the plans for improving the real and fiscal statistics need to be updated.
No data ROSC is available. 


\section{Lebanon: Table of Common Indicators Required for Surveillance As of March 12, 2009}

\begin{tabular}{|c|c|c|c|c|c|}
\hline & $\begin{array}{l}\text { Date of latest } \\
\text { observation }\end{array}$ & $\begin{array}{l}\text { Date } \\
\text { received }\end{array}$ & $\begin{array}{l}\text { Frequency of } \\
\text { Data }^{6}\end{array}$ & $\begin{array}{l}\text { Frequency of } \\
\text { Reporting }\end{array}$ & $\begin{array}{l}\text { Frequency of } \\
\text { publication }^{6}\end{array}$ \\
\hline Exchange Rates & 03/11/09 & 03/12/09 & $\mathrm{D}$ & $\mathrm{D}$ & $\mathrm{D}$ \\
\hline $\begin{array}{l}\text { International Reserve Assets and } \\
\text { Reserve Liabilities of the Monetary } \\
\text { Authorities }^{1}\end{array}$ & $01 / 2009$ & $02 / 2009$ & $\mathrm{M}$ & $\mathrm{M}$ & M \\
\hline Reserve/Base Money & $01 / 2009$ & $02 / 2009$ & M & M & M \\
\hline Broad Money & $01 / 2009$ & $03 / 2009$ & M & M & M \\
\hline Central Bank Balance Sheet & $01 / 2009$ & $02 / 2009$ & M & M & M \\
\hline $\begin{array}{l}\text { Consolidated Balance Sheet of the } \\
\text { Banking System }\end{array}$ & $01 / 2009$ & $03 / 2009$ & M & M & M \\
\hline Interest Rates ${ }^{2}$ & $12 / 2008$ & $02 / 2009$ & M & $M$ & M \\
\hline Consumer Price Index & $01 / 2009$ & $02 / 2009$ & $\mathrm{M}$ & M & $\mathrm{M}$ \\
\hline \multicolumn{6}{|l|}{$\begin{array}{l}\text { Revenue, Expenditure, Balance and } \\
\text { Composition of Financing }{ }^{3}-\text { General } \\
\text { Government }^{4}\end{array}$} \\
\hline $\begin{array}{l}\text { Revenue, Expenditure, Balance and } \\
\text { Composition of Financing }{ }^{3}-\text { Central } \\
\text { Government }\end{array}$ & $12 / 2008$ & $02 / 2009$ & $\mathrm{M}$ & M & $\mathrm{M}$ \\
\hline $\begin{array}{l}\text { Stocks of Central Government and } \\
\text { Central Government-Guaranteed Debt }{ }^{5}\end{array}$ & $12 / 2008$ & $02 / 2009$ & M & M & M \\
\hline External Current Account Balance & Q3/2008 & $01 / 2009$ & Q & Q & Q \\
\hline $\begin{array}{l}\text { Exports and Imports of Goods and } \\
\text { Services }\end{array}$ & Q3/2008 & $01 / 2009$ & Q & Q & Q \\
\hline GDP/GNP & 2007 & $11 / 2008$ & $A$ & $A$ & $A$ \\
\hline Gross External Debt & $12 / 2008$ & 02/2009 & M & M & M \\
\hline \multicolumn{6}{|l|}{ International Investment Position } \\
\hline $\begin{array}{l}{ }^{1} \text { Includes reserve assets pledged or oth } \\
{ }^{2} \text { Both market-based and officially-deterr } \\
\text { bonds. } \\
{ }^{3} \text { Foreign, domestic bank, and domestic } \\
{ }^{4} \text { The general government consists of th } \\
\text { funds) and state and local governments } \\
{ }^{5} \text { Including currency and maturity compc } \\
{ }^{6} \text { Includes external gross financial asset } \\
{ }^{6} \text { Daily (D); Weekly (W); Monthly (M); Qu }\end{array}$ & $\begin{array}{l}\text { Nise encumber } \\
\text { led, including } d \\
\text { nbank financin } \\
\text { entral governm } \\
\text { ion. } \\
\text { Id liability positi } \\
\text { terly (Q); Annua }\end{array}$ & $\begin{array}{l}\text { as well as } r \\
\text { unt rates, } \\
\text { (budgetar) } \\
\text { vis-à-vis n } \\
\text { (A); Irregul }\end{array}$ & $\begin{array}{l}\text { derivative posit } \\
\text { ney market rate } \\
\text { nds, extra buds } \\
\text { esidents. } \\
\text { l); or Not Avail }\end{array}$ & $\begin{array}{l}\text { ates on treasu } \\
\text { rynds, and } s \\
\text { (NA). }\end{array}$ & $\begin{array}{l}\text { s, notes and } \\
\text { security }\end{array}$ \\
\hline
\end{tabular}


Public Information Notice (PIN) No. 09/49 FOR IMMEDIATE RELEASE April 17, 2009
International Monetary Fund $70019^{\text {th }}$ Street, NW

Washington, D. C. 20431 USA

\section{IMF Executive Board Concludes 2009 Article IV Consultation with Lebanon}

On April 15, 2009, the Executive Board of the International Monetary Fund (IMF) concluded the Article IV consultation with Lebanon. ${ }^{1}$

\section{Background}

The Lebanese financial system has so far weathered the global financial crisis. Deposit inflows decelerated briefly in the aftermath of the Lehman Brothers bankruptcy, but have resumed at a rapid pace since then, and deposit dollarization has been declining steadily. Consequently, the Bank of Lebanon (BdL) has continued to accumulate international reserves at a swift pace. Eurobond spreads have come down markedly since spiking following the Lehman bankruptcy, and are now below the emerging market average. Helped by strict financial oversight, the domestic financial system has had very little exposure to distressed financial products or markets and remains liquid.

Despite its vulnerabilities, the Lebanese economy has shown a remarkable macroeconomic performance. Lebanon's public debt-to-GDP ratio remains very high, its large banking system is highly exposed to the sovereign and dependent on nonresident deposit inflows, and the country lies at the crossroads of regional political tensions. Nonetheless, Lebanon has achieved a strong macroeconomic performance, helped by prudent policies and an improvement of the

\footnotetext{
${ }^{1}$ Under Article IV of the IMF's Articles of Agreement, the IMF holds bilateral discussions with members, usually every year. A staff team visits the country, collects economic and financial information, and discusses with officials the country's economic developments and policies. On return to headquarters, the staff prepares a report, which forms the basis for discussion by the Executive Board. At the conclusion of the discussion, the Managing Director, as Chairman of the Board, summarizes the views of Executive Directors, and this summary is transmitted to the country's authorities.
} 
political and security situation after the May 2008 Doha agreement. Real GDP growth exceeded 8 percent in 2008. CPI inflation dropped to 4 percent in January 2009, down from the double digits briefly reached last summer in the wake of soaring international food and fuel prices. With a primary fiscal balance of 0.5 percent of GDP, the debt-to-GDP ratio declined by 6 percentage points to 162 percent of GDP in 2008. All end-December quantitative targets under the Emergency Post-Conflict Assistance -supported program were met with substantial margins.

The global recession and tight international capital markets weigh on the economic and financial outlook. Lower global liquidity and economic growth, particularly in the Gulf, are likely to affect merchandise exports, tourism, remittances, foreign direct and portfolio investment, and deposit inflows. Economic growth in Lebanon is likely to slow to 3 percent this year, and deposit growth could decline to about 10 percent from over 15 percent in 2008 . Nonetheless, helped by a reduced oil import bill and ongoing deposit dedollarization, international reserves are likely to increase further. Inflation will likely remain low, in line with international price trends.

\section{Executive Board Assessment}

Executive Directors welcomed the remarkable resilience of the Lebanese economy in the face of the global financial crisis, and commended the authorities for their macroeconomic policy discipline and strict oversight of the financial system. Their implementation of the program supported by EPCA has contributed to a strong economic and financial performance and a reduction in the government debt-to-GDP ratio.

Directors considered that the deepening global recession, unsettled international credit markets, and Lebanon's exposure to regional spillovers underscore the importance of making further progress in addressing Lebanon's macroeconomic and financial vulnerabilities. Near-term policies should aim at mitigating downside risks by safeguarding the recent progress made toward achieving debt sustainability and strengthening the external position. This will involve continued prudent fiscal and monetary policies, vigilant financial supervision, proactive contingency planning, and a resumption of the Paris III reform policy agenda to reduce structural vulnerabilities.

Directors supported the authorities' monetary policy aimed at safeguarding the exchange rate peg and facilitating a further buildup of international reserves. The large currency mismatches in the debt held by the governmental, corporate, and household sectors, along with the high level of government foreign currency debt and debt-service obligations, underscore the central role played by the peg in maintaining financial stability. Given heightened near-term risks, Directors agreed that there is little scope for lowering interest rates over the coming months. They took note of the staff assessment that the real effective exchange rate of the Lebanese pound appears to be broadly in line with fundamentals.

Directors cautioned that Lebanon's still very-high level of government debt and the need to support the exchange rate peg leave little room for countercyclical fiscal policy. A number of Directors encouraged the authorities to aim for a higher primary fiscal surplus than implied in the draft budget to reduce the debt burden, while a few others saw the planned pause in fiscal 
consolidation as justified by the slowdown in economic activity. Directors recommended that any revenue overperformance or capital spending shortfall in the 2009 budget be saved. They were encouraged by the authorities' assurance that implementation of the 2009 budget will be prudent, and their readiness to consider additional measures if needed to maintain the government debt-to-GDP ratio unchanged, and ensure government financing in the event of a shortfall in deposit inflows.

Directors welcomed the reintroduction of gasoline excise taxes, which will help bolster the revenue position. They considered that carefully targeting social expenditures would lead to a more efficient allocation of public resources and achieve social and development objectives better than generalized public sector wage increases.

Directors were encouraged by the resilience and profitability of the banking sector in the face of the global crisis. They commended the authorities for their prudent regulation and supervision of the sector, and the progress they have made in strengthening the bank resolution framework. At the same time, banks' large exposure to the sovereign, maturity mismatches, and the still-high degree of dollarization constitute vulnerabilities. Directors therefore stressed the need for continued vigilance in bank regulation and supervision.

Directors considered that progress on structural reforms under the Paris III reform agenda, especially in the energy sector, will warrant heightened attention in the period ahead. This should include a revision of electricity tariffs to ensure cost recovery, which will boost Lebanon's growth potential and reduce a large drain on budgetary resources. The privatization of the mobile telecommunications providers as soon as market conditions allow would promote private sector growth and reduce debt-related vulnerabilities. Directors underscored that fiscal reforms, including an increase in the VAT, will be needed to achieve the desired sizeable primary fiscal surplus in the medium term. They stressed the importance of timely and full disbursement of donor commitments to support Lebanon's reform agenda, including through the provision of budgetary support.

Public Information Notices (PINs) form part of the IMF's efforts to promote transparency of the IMF's views and analysis of economic developments and policies. With the consent of the country (or countries) concerned, PINs are issued after Executive Board discussions of Article IV consultations with member countries, of its surveillance of developments at the regional level, of post-program monitoring, and of ex post assessments of member countries with longer-term program engagements. PINs are also issued after Executive Board discussions of general policy matters, unless otherwise decided by the Executive Board in a particular case. 


\section{Statement by Shakour Shaalan, Executive Director for Lebanon April 15, 2009}

1. On behalf of the Lebanese authorities, I would like to express my appreciation to staff, Management, and the Executive Board for their continued constructive engagement with Lebanon. The authorities appreciated the helpful discussions with staff during the mission, which focused on preserving financial and economic stability in the near term, while pursuing the Paris III objectives of continued debt reduction and structural reforms over the medium term.

\section{Recent Developments and Outlook}

2. Lebanon's economy has thus far shown significant resilience to the ongoing global financial and economic crisis. Underpinned by sound macroeconomic policies and an improved political and security environment, real GDP growth exceeded 8 percent in 2008, driven by construction and tourism. Inflation declined to 4 percent in January 2009, after having reached double digits last summer on account of high international food and fuel prices. Moreover, the authorities made further progress toward fiscal consolidation, with a realization of a primary fiscal surplus of 0.5 percent of GDP and a lowering of the debt-to-GDP ratio by 6 percentage points to 162 percent in 2008. At the same time, deposit inflows continued to increase at a rapid pace after decelerating briefly following the Lehman Brothers bankruptcy, deposit dollarization declined steadily, and the Banque du Liban (BdL) continued to rapidly accumulate international reserves. Against this background, all end-December 2008 quantitative targets under the Emergency Post-Conflict Assistance (EPCA)-supported program were met with substantial margins. Implementation of the structural reform agenda was slow, however, reflecting the approach of the general elections set for June this year, as well as a difficult international environment for privatization.

3. Notwithstanding this remarkable performance, a worsening of the global financial and economic outlook, particularly in the Gulf, will adversely weigh on Lebanon's economic prospects for 2009, in terms of lower receipts from tourism, remittances, foreign direct and portfolio investment, and deposit inflows. The authorities are well aware of the potential risks stemming from a slowdown in deposit growth, as domestic banks contribute to a large extent to financing the country's fiscal deficits. Accordingly, the authorities' policy objectives in the near term are to minimize the possible impact of the aforementioned risks by further building international reserves, safeguarding fiscal achievements, containing financing needs, and strengthening the banking sector. They remain fully committed to the objectives of the EPCA, which provides macroeconomic and financial discipline to their policy framework while anchoring progress towards structural reforms. They also remain committed to the implementation of the Paris III reform agenda over the medium term, particularly in the areas of fiscal consolidation, the privatization of the telecommunications sector, and the reform of the energy sector. At the same time, continued strong international 
support remains essential to help Lebanon reduce its economic vulnerabilities. In particular, it is important that donors fully carry through their financial commitments made at the Paris III conference, in a timely fashion. The authorities continue to actively seek flexibility from donors to convert project loans pledges into budgetary support to further reduce the debt burden. They appreciate the support shown by the Fund in this regard.

\section{Monetary and Exchange Rate Policies}

4. The monetary policy framework has helped maintain confidence in the Lebanese financial system. The exchange rate peg continues to serve the economy well by providing a firm anchor to financial stability. It has proved crucial in this regard, given balance sheet risks related to widespread dollarization and the government's high foreign currency debt servicing obligations. The authorities agree with staff's assessment that the real exchange rate remains broadly in line with fundamentals.

5. Mindful of continued strains in the global financial outlook, the BdL aims at further strengthening its international reserves buffer to preserve confidence and support deposit growth. This would be achieved by maintaining the interest rate differential between domestic currency and foreign currency rates at the current level. Admittedly, given the decline in international interest rates, the policy of reserve accumulation entails a high cost for the BdL balance sheet. Once more stable and predictable market conditions prevail, the central bank should be in a better position to consider a further reduction in domestic currency interest rates when deposit growth stabilizes at a comfortable pace. Going forward, fiscal adjustment and improved confidence in the economy would help reduce dollarization, which would facilitate a further build-up of net international reserves and strengthen the BdL's income position.

\section{Fiscal Policy and Reforms}

6. The budget for 2009 has been framed against the background of an expected slowdown in economic activity and the associated potential increase in social needs. Accordingly, the draft budget (expected to be submitted to Parliament in the near future) envisages a balanced primary account and a gross debt-to-GDP ratio that remains constant at 162 percent. Fiscal space is being created through the reintroduction of gasoline excises, the reduced need for budgetary transfers to Electricité du Liban resulting from lower fuel costs, the delayed privatization of the mobile phone companies, and the implementation of revenue measures envisaged under EPCA. These additional resources would help finance the increase in spending on wages and salaries that has been approved last year, as well as much needed higher capital expenditures. The authorities are fully committed to the EPCA's fiscal targets. Accordingly, implementation of the 2009 budget will be prudent, and the authorities stand ready to consider additional measures if needed to achieve the budgetary objectives. The authorities have also prepared a contingency anti-crisis plan aimed at boosting economic activity, with minimal effects on the fiscal balance. 
7. Important progress has been made in the area of budgetary reforms. Parliament approved the tax procedure code at end-2008. A cash management unit was also established, and is undertaking a pilot project on monthly payment forecasts with three line ministries. The draft Global Income Tax law should be submitted to the Council of Ministers and Parliament in the coming months. The restructuring of the tax administration has been initiated, and the Treasury Single Account legislation is under examination in Parliament.

8. Despite the likely slowdown in deposit growth, the authorities expect to meet the 2009 financing needs from the market. However, should the approach of the elections or a protracted global recession lead to a critical drop in deposit inflows, the authorities stand ready to respond appropriately with a combination of measures, including fiscal adjustment, a lower pace of reserve accumulation, higher interest rates, and possibly additional use of Fund resources.

\section{Financial Sector}

9. Effective regulation and supervision, coupled with a deposit-based funding structure, have shielded the domestic financial sector from exposure to international financial risks, and thus from the effects of the global financial crisis. Nevertheless, in the wake of the crisis, the Banking Control Commission (BCC) has strengthened reporting requirements on domestic and foreign operations, carried out stress tests for the banking system, and intensified on-site inspections. Moreover, the BdL has recently recommended limiting dividend payments to 25 percent of 2008 profits in order to further enhance the already high bank capitalization. Finally, the authorities have prepared a draft legislation for the creation of the regulatory authority for financial markets. They further reinforced the banking resolution framework with the adoption of a revised bank merger law aimed at preventing to the extent possible bank failures by encouraging mergers and takeovers by sounder banks instead. Plans to reform the deposit insurance fund are also underway. 